\title{
Systematic Review of
} Biopsychosocial Prognostic Factors for Return to Work After Acute Orthopedic Trauma: A 2020 Update

\author{
Hong Phuoc Duong ${ }^{1 * t}$, Anne Garcia ${ }^{2 \dagger}$, Roger Hilfiker ${ }^{3}$, Bertrand Léger $^{1}$ and \\ François Luthi ${ }^{1,2,4}$
}

${ }^{1}$ Department of Medical Research, Clinique Romande de Réadaptation, Sion, Switzerland, ${ }^{2}$ Department of Musculoskeletal Rehabilitation, Clinique Romande de Réadaptation, Sion, Switzerland, ${ }^{3}$ School of Health Sciences, HES-SO Valais-Wallis, Sion, Switzerland, ${ }^{4}$ Department of Physical Medicine and Rehabilitation, Orthopedic Hospital, Lausanne University Hospital, Lausanne, Switzerland

OPEN ACCESS

Edited by:

Paul Kuijer,

Amsterdam UMC, Public and

Occupational Health, Netherlands

Reviewed by:

Yvonne Heerkens, HAN University of Applied

Sciences, Netherlands

Charles Sebiyo Batcho,

Laval University, Canada

*Correspondence:

Hong Phuoc Duong

hongphuoc.duong@crr-suva.ch

†These authors have contributed equally to this work and share first authorship

Specialty section:

This article was submitted to Disability, Rehabilitation, and Inclusion, a section of the journal Frontiers in Rehabilitation Sciences

Received: 08 October 2021 Accepted: 17 December 2021

Published: 04 February 2022

Citation:

Duong HP, Garcia A, Hilfiker R, Léger $B$ and Luthi $F$ (2022) Systematic Review of Biopsychosocial Prognostic Factors for Return to Work After Acute Orthopedic Trauma: A 2020 Update. Front. Rehabilit. Sci. 2:791351 doi: 10.3389/fresc.2021.791351
Objective: To provide updated evidence on prognostic factors for return to work (RTW) in the early and late phases after acute orthopedic trauma from a biopsychosocial perspective.

Methods: A systematic review of articles indexed in the MEDLINE, CINAHL, and Embase databases between 2010 and 2020 was performed. The inclusion criteria were cohort studies of employed populations sustaining acute orthopedic trauma with follow-up data on RTW. Biopsychosocial prognostic factors for RTW must be reported in the multiple regression models and divided into early ( $\leq 6$ months) and late phases (> 6 months) postinjury. Two reviewers performed study selection, assessed the risk of bias and quality using the Quality in Prognosis Studies (QUIPS) tool and the Newcastle-Ottawa Scale (NOS), and extracted data independently.

Results: Thirty articles were included with a follow-up period of 1-58 months. Based on the QUIPS tool, 7 studies (23\%) were considered to have a low risk of bias, and 21 studies (70\%) were considered to have a moderate risk of bias. Based on the NOS, the quality was high in $87 \%$ of the included studies. The RTW rates ranged from $22 \%$ to $74 \%$ in the early phase and from $44 \%$ to $94 \%$ in the late phase. In the early phase, strong evidence was found for injury severity. In the late phase, strong evidence was found for age, injury severity, level of pain, self-efficacy, educational level, blue-collar work, and compensation status; moderate evidence was found for recovery expectations and physical workload. There was limited or inconsistent evidence for the other factors.

Conclusion: Based on the levels of evidence, injury severity should be considered as one of the key barriers to RTW in the early and late phases postinjury. This finding underlines the need for serious injury prevention efforts. Our results also emphasize the multifaceted actions of the biopsychosocial model to facilitate RTW: promoting policies for older injured workers, improving access to medical and rehabilitation facilities, and adapting physical workload. Multiple other factors are likely important but require additional high-quality studies to assess their role in the RTW process.

Keywords: return to work, orthopaedic trauma, injury, work disability, prognostic factors, biopsychosocial factors 


\section{INTRODUCTION}

Acute orthopedic trauma represents one of the most common injuries in workplace accidents, traffic accidents, and other types of accidents (1). It is also responsible for individual disability and loss of workdays and implies a substantial economic and societal burden $(2,3)$. According to the official statistical report of the Swiss accident insurance fund, among 850,000 accidents reported (8.7 million inhabitants) in 2018, orthopedic trauma accounts for $85 \%$ of all injuries (4). The mean direct and indirect costs due to orthopedic trauma in Switzerland between 2014 and 2018 were 3.96 billion euros (4). According to a systematic review of 204 studies in $2020,13 \%$ of patients sustaining orthopedic trauma had lost employment at 1 year postinjury, and the mean number of days absent from work was 102 days (3).

Based on these data, return to work (RTW) after orthopedic trauma has become a key outcome for people of working age. RTW marks a return to financial independence for the individual and the end of compensation benefits for society. From an individual point of view, RTW is associated with better psychological well-being, self-esteem, and social connectedness (5). However, the definition and measurement of RTW outcome remain highly heterogeneous from study to study (6). A synthesis of the measurement of RTW outcome in the literature may help to clarify its operationalization.

Furthermore, the identification of prognostic factors for RTW remains the focus of many studies in the field. RTW seems to be influenced by different personal and environmental determinants due to its complex and multidimensional nature (7). Indeed, the usual biomedical model cannot fully explain the RTW process for patients with musculoskeletal disorders (8). The biomedical model, based on a dualistic mind-body viewpoint, fails to take into account psychological, social, and health system aspects. These psychosocial factors were, however, widely recognized as having an independent influence on RTW (7-9). Another limitation of the biomedical model is its inability to explain the interaction between injury severity and other psychosocial factors in predicting the longterm outcome. The biopsychosocial (BPS) model developed by George Engel in 1977 (10), based on a holistic approach, might overcome the limitations of the traditional biomedical framework for predicting multidimensional outcomes such as RTW (11). The underlying assumptions of the BPS model rely on the complex and non-linear interactions between the biological, psychological, and social determinants that affect disease outcomes (12). Based on this model, the RTW process depends not only on biomedical characteristics but also on personal and environmental factors (workplace, healthcare system, compensation policy) (13). Early identification of BPS factors associated with RTW is of importance to help in developing effective interventions to prevent work disability and

Abbreviations: BPS, Biopsychosocial; NOS, Newcastle-Ottawa Scale; PRISMA, Preferred Reporting Items for Systematic reviews and Meta-Analysis; PROBAST, Prediction model risk of bias assessment tool; QUIPS, Quality in Prognosis Studies; RTW, Return to work. subsequently in reducing the personal and societal burden of orthopedic trauma.

In 2010, the prognostic factors involved in the RTW process in patients with orthopedic trauma were presented in a systematic review by Clay et al. (9). At that time, the literature was scarce, and the quality of the studies was limited. According to an earlier review (9), two factors of strong evidence identified were educational levels and blue-collar work, whereas three factors of moderate evidence were self-efficacy, injury severity, and compensation status. Over the past 10 years, the emergence of new evidence has raised the need to perform an updated review on this topic.

In this systematic review, we updated the latest evidence on prognostic factors for RTW in employed populations sustaining acute orthopedic trauma by reviewing studies indexed in three large databases between 2010 and 2020. Prognostic factors were evaluated using a two-tiered strategy (significant and nonsignificant effects) and classified into the early or late phase postinjury using a 6-month cutoff. This cutoff point was used when assuming that some orthopedic injuries (for example, fractures) might take up to 6 months to recover (3) and that the influence of some prognostic factors on RTW might vary in a timely fashion (14).

\section{METHODS}

\section{Protocol and Registration}

The review protocol was performed following the "Preferred Reporting Items for Systematic reviews and Meta-Analysis" (PRISMA) recommendations (15) (see Appendix PRISMA 2020 checklist). The research protocol was registered in PROSPERO (CRD42017074234).

\section{Eligibility Criteria}

This literature review was extended to articles written in English, French, and German. The articles had to be available in full text and as published articles (conference papers/abstracts were excluded).

We included studies published between January 1, 2010 and December 31, 2020 and fulfilled the following criteria:

-Study designs: prospective or retrospective studies with longitudinal data on RTW.

-Participants: studies on individuals with acute orthopedic trauma only or orthopedic trauma represented a minimum of $75 \%$ of the sample and were employed at the time of injury. Acute orthopedic trauma is defined as any injury (strains/sprains, contusions, dislocations, and fractures) to the musculoskeletal system due to an unintentional accident.

-Outcome measures: RTW was defined as the return to the preinjury or modified job (fully or partially) or a period of time off work or not being prevented from working at a certain follow-up measurement or RTW sustained for a long period.

-Prognostic factors: Biological (age, gender, level of pain, etc.), psychological (depression, anxiety, etc.), and social factors (education, occupation, work-related environment, etc.) were eligible. Considering the multidimensional nature of work incapacity, the factors must be reported in the multiple 
regression models. We did not include the unadjusted effects of prognostic factors in the analysis because their effects may completely disappear after adjustment and are therefore relatively uninformative. Adjusted effects of prognostic factors were extracted for data analysis and were divided into the early phase ( $\leq 6$ months from injury) and the late phase ( $>6$ months from injury).

Exclusion criteria were as follows: whiplash, brain injury, medullar injury, or injuries resulting from occupational repeated trauma; no precision about the percentage of orthopedic trauma, sample size lower than 80 individuals (to rule out findings with low statistical power), soldiers or military population; and retrospective without follow-up data on RTW or cross-sectional studies (to limit recall bias).

\section{Search Strategy}

We performed a literature search in the MEDLINE, CINAHL, and Embase databases using keywords covering three areas: (a) RTW or work absence or work disability or sick leave or time off work; (b) orthopedic trauma or injury or fracture; and (c) prognostic or prognosis or risk factors or outcome. Additional manual searching of reference lists of all included studies was performed. The terms within each area were combined with an OR Boolean operator, and then, the three areas were combined with an AND Boolean operator. The search results were uploaded to the Endnote program. The duplicates were removed. Two of the authors (AG and $\mathrm{RH}$ ) made the first selection of articles based on the abstracts from 2010 to 2017 and (AG and HPD) from 2017 to 2020. Next, the full-text articles were obtained by the researchers, and they included the relevant articles independently according to the predefined criteria and then compared their choices. The final decision of inclusion was based on consensus. The last senior author (FL) made the final decision if no consensus was reached.

\section{Data Extraction and Analysis}

In accordance with the Critical Appraisal and Data Extraction for Systematic Reviews of Prediction Modeling Studies (CHARMS) checklist (16) for data extraction, the following elements were extracted from the included studies: first author and year, country, setting, nature of the trauma, type of study, definition of the outcome, sample size in the final multiple regression model, duration of follow-up, percentage lost to follow-up, predictor measurements, and RTW rate. The data from selected studies were extracted independently by the aforementioned reviewers. Significant barriers and facilitators for RTW and also nonsignificant factors were reported with their statistical values. Odds ratios, relative rate ratios, hazard ratios, or regression coefficients with $95 \%$ confidence intervals were extracted from the final multivariable models with imputation if available. Finally, we classified the factors according to the BPS categories and their implications in the early or late phase postinjury. We planned to conduct meta-analyses where this was appropriate; otherwise, we summarized narratively.

\section{Risk of Bias and Quality Assessment}

For studies of prognostic factors, the Quality in Prognosis Studies (QUIPS) tool was used to assess the risk of bias (17). The QUIPS tool has six domains: (1) study participants, (2) study attrition, (3) prognostic factor measurement, (4) outcome measurement, (5) study confounding, (6) statistical analysis and reporting. Each domain includes three to seven items that are judged separately with the response "yes," "partial," "no," or "unsure." Based on the ratings of the included items, the risk of bias within each domain is expressed as high, moderate, or low. A study was classified as having a low risk of bias when all domains were rated as having a low risk of bias or up to one moderate risk of bias. A study was classified as having a high risk of bias if two or more of the domains were rated as having a high risk of bias. All studies in between were classified as having a moderate risk of bias.

For studies presenting a prognostic model, prediction model risk of bias assessment tool (PROBAST) was used to assess the risk of bias (18). The PROBAST consists of 20 signaling questions grouped into four domains: participant selection, predictors, outcome, and analysis (18). All signaling questions answered as "yes" indicate an absence of bias. Any signaling question answered as "no" or "probably no" flags the potential for bias; assessors would need to use their judgment to determine whether the domain should be rated as high, low, or unclear risk of bias.

The quality of the included studies was assessed by the Newcastle-Ottawa Scale (NOS) (19). The NOS consists of three categories of parameters (selection, comparability, and outcome) with a total of 9 points. A study of a total of NOS scores $>6$ points, 5 or 6 points, and $\leq 4$ points was rated as having high, medium, and low quality, respectively.

Two of the authors jointly (AG and HPD) assessed the risk of bias and quality of the articles. Disagreements were resolved by consulting the last author to achieve consensus.

\section{Levels of Evidence}

To be retained, the prognostic factors must have been measured in the multiple regression model. To compare with the previous review on RTW (9), the levels of evidence were determined by using a rating system similar to that used by Scholten-Peeters (20). According to this system, there were four levels of evidence: strong/moderate/limited/inconsistent. Strong evidence: consistent findings were found in at least two highquality cohorts with a low risk of bias. Moderate evidence: consistent findings were found in one high-quality cohort with a low risk of bias and one or more cohorts with a moderate or high risk of bias regardless of the level of quality. Limited evidence: consistent findings in one regardless of the level of risk of bias or more cohorts with moderate or high risk of bias. Inconsistent evidence: contradictory findings were found irrespective of study quality.

\section{RESULTS}

\section{Characteristics of Included Studies}

The flow diagram is presented in Figure 1, and reasons for exclusions at each stage are provided. The initial search yield 2,541 articles. After removing duplicates and screening titles and 


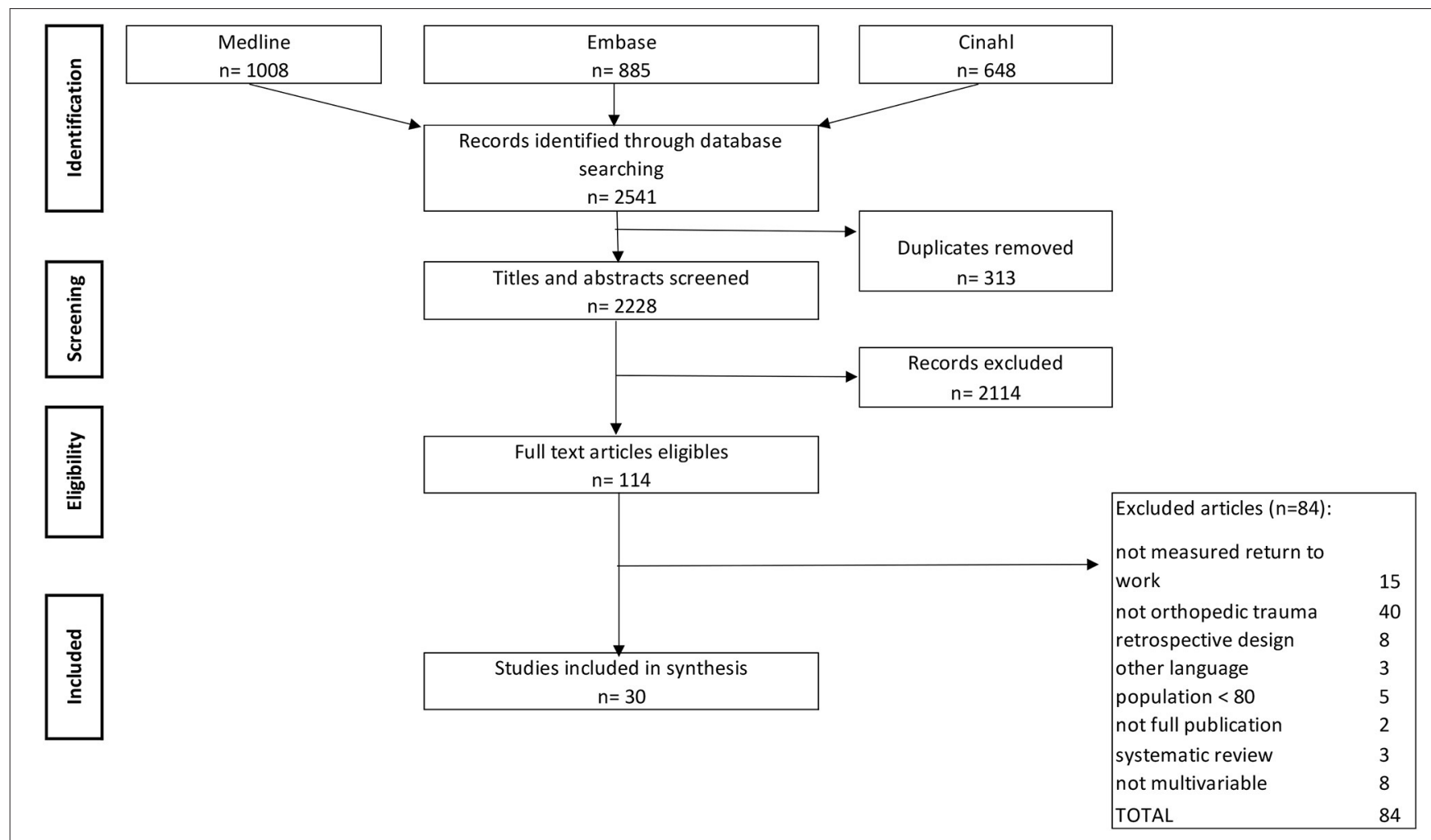

FIGURE 1 | Flow diagram for selection of studies for this systematic review.

abstracts, 114 articles were retained for further assessment of eligibility. After reading these full-text articles, 30 articles met the inclusion criteria.

The characteristics of the selected studies are summarized in Table 1. Twenty-five studies were prospective (21-37, 41-47, 50), and five were retrospective but included longitudinal data on RTW $(38-40,48,49)$. The follow-up time ranged from 1 to 58 months postinjury. The RTW rates ranged from 22 to $74 \%$ in the early phase postinjury $(22,28,35,36,41,43,44)$ and from 44 to $94 \%(21-32,34,37,38,40,42,43,45,46,48-50)$ in the late phase.

Return to work was defined as a completion of a period of four consecutive weeks on the labor market in one study (39), as a sustained outcome for 3 months in one study (40), as a return to any form of work (the same or modified work, full time or part time) in 18 studies $(21,22,24-27,30,32,33,37,41-$ $46,48,49)$, or as not being prevented from working for any days in the last 4 weeks in one study (36). Nine studies did not provide the definition $(23,28,29,31,34,35,38,47,50)$. Concerning its measurement, RTW was reported as a binary outcome (yes/no status) in 23 studies (21-26, 28, 30-34, 36-38, 40-44, 47, 48, 50), as time from injury to RTW in 6 studies $(27,29,35,39,45,46)$, or as the number of days paid for work disability in one study (49).

The rates of loss to follow-up were reported in 25 studies (21$28,30-32,34,36-38,40-46,48-50)$, ranging from 1 to $53 \%$. The studies were conducted in 12 different countries of high or uppermiddle income (Australia, Switzerland, Taiwan, Canada, Israel, the United Kingdom, Germany, the Netherlands, Denmark, New
Zealand, China, and Iran). Of note, most European countries were the part of universal health coverage, whereas in many other countries (Australia and the United Kingdom), private companies were involved in compensation with different sick pay schemes.

\section{Risk of Bias and Quality Assessment}

A majority of the included studies (97\%) reported the statistical estimates of an array of predictors of RTW outcome, except one (42) that presented a prognostic model for RTW with external validation. Therefore, we used the QUIPS tool, which was developed to assess the risk of bias in predicting factor studies for all included studies. Figure 2 represents the overall risk of bias of the included studies using the QUIPS tool and also the ratings of each domain. The agreement between the two reviewers for the QUIPS tool was 87\% (26 out of 30 studies). Disagreement was found in the rating of study attrition and confounding factors. Seven studies $(23 \%)$ were rated as having a low risk of bias $(27,32,36,42,43,45,47), 2$ studies (7\%) as having a high risk of bias $(35,48)$, and the 21 remaining studies $(70 \%)$ as having a moderate risk $(21-26,28-31,33,34,37-41,44,46,49$, 50).

For the study presenting a prognostic model for RTW (42), apart from the QUIPS, we also used PROBAST to assess the risk of bias. The risk of bias in the four domains (participants, predictors, outcome, and analysis) based on PROBAST was low; therefore, an overall low risk of bias was drawn. 


\begin{tabular}{|c|c|c|c|c|c|c|c|c|c|c|}
\hline References & Country & Setting & Nature of injuries & $\begin{array}{l}\text { Study } \\
\text { design }\end{array}$ & $\begin{array}{l}\text { Outcome } \\
\text { definition }\end{array}$ & $\begin{array}{l}\text { Follow-up } \\
\text { (months) }\end{array}$ & $\begin{array}{l}\text { Predictors } \\
\text { measures }\end{array}$ & $\begin{array}{l}\text { Lost to } \\
\text { follow-up }\end{array}$ & $\begin{array}{l}\text { Number } \\
\text { in multiple } \\
\text { regression } \\
\text { analysis }\end{array}$ & $\begin{array}{l}\text { RTW rates } \\
\text { (months)* }\end{array}$ \\
\hline $\begin{array}{l}\text { Amick et al. } \\
\text { (21) }\end{array}$ & Canada & $\begin{array}{l}\text { Regional } \\
\text { database }\end{array}$ & $\begin{array}{l}\text { Back + upper } \\
\text { extremities trauma }\end{array}$ & Prospective & $\begin{array}{l}\text { RTW status (any } \\
\text { type of work) } \\
\text { yes/no }\end{array}$ & 6,12 & $\begin{array}{l}1 \text { month } \\
\text { postinjury }\end{array}$ & $31 \%$ & 577 & $\begin{array}{l}74 \%(6) \\
76 \%(12)\end{array}$ \\
\hline $\begin{array}{l}\text { Ballabeni et } \\
\text { al. (22) }\end{array}$ & Switzerland & Clinic & Orthopedic trauma & Prospective & $\begin{array}{l}\text { Return to any } \\
\text { occupation }\end{array}$ & $3,12,24$ & $\begin{array}{l}\text { At entry } \\
\text { and } \\
\text { discharge }\end{array}$ & $45 \%$ & 291 & $\begin{array}{l}37 \%(3), 45 \% \\
(12), 56 \%(24)\end{array}$ \\
\hline $\begin{array}{l}\text { Busse et al. } \\
\text { (23) }\end{array}$ & Canada & $\begin{array}{l}\text { Multi- } \\
\text { center }\end{array}$ & Tibial shaft fracture & Prospective & NA & 12 & $\begin{array}{l}6 \text { weeks } \\
\text { after injury }\end{array}$ & $29 \%$ & 186 & $64 \%(12)$ \\
\hline $\begin{array}{l}\text { Clay et al. (24) } \\
\text { Clay et al. (25) } \\
\text { Clay et al. (26) }\end{array}$ & $\begin{array}{l}\text { Australia } \\
\text { Australia } \\
\text { Australia }\end{array}$ & $\begin{array}{l}\text { Victorian } \\
\text { hospital } \\
\text { dataset }\end{array}$ & $\begin{array}{l}\text { Acute orthopedic } \\
\text { injuries }\end{array}$ & Prospective & $\begin{array}{l}\text { RTW to full duties } \\
\text { or modified work }\end{array}$ & 6 & $\begin{array}{l}\text { Preinjury } \\
\text { and } 2 \\
\text { week } \\
\text { postinjury }\end{array}$ & $10 \%$ & 168 & $\begin{array}{l}44 \% \text { return to } \\
\text { full duties (6), } \\
56 \% \text { return to } \\
\text { modified work } \\
\text { (6) }\end{array}$ \\
\hline Clay et al. (27) & Australia & Multicenter & $\begin{array}{l}\text { Orthopedic trauma } \\
>75 \%\end{array}$ & Prospective & $\begin{array}{l}\text { Time until the first } \\
\text { RTW on either } \\
\text { preinjury or } \\
\text { reduced hours }\end{array}$ & 12 & $\begin{array}{l}1-6 \text { week } \\
\text { postinjury }\end{array}$ & $53 \%$ & 186 & $81 \%(12)$ \\
\hline Dinh et al. (28) & Australia & Hospital & Trauma patients & Prospective & NA & $\begin{array}{l}3,6 \\
\text { postdischarge }\end{array}$ & At baseline & $20 \%$ & 179 & $74 \%$ (3), $76 \%$ (6) \\
\hline $\begin{array}{l}\text { Eisele et al. } \\
\text { (29) }\end{array}$ & Germany & 9 centers & Hand trauma & Prospective & $\begin{array}{l}\text { Time between } \\
\text { injury and RTW }\end{array}$ & $1.5,3,6$ & $\begin{array}{l}\text { Fist } \\
\text { admission }\end{array}$ & & 231 & $77 \%(6)$ \\
\hline $\begin{array}{l}\text { Ekegren et al. } \\
\text { (30) }\end{array}$ & Australia & $\begin{array}{l}\text { VOTOR } \\
\text { registry }\end{array}$ & $\begin{array}{l}\text { Hip fracture } \\
\text { patient }\end{array}$ & Prospective & $\begin{array}{l}\text { Paid employment, } \\
\text { same workplace, } \\
\text { same role, or } \\
\text { others }\end{array}$ & 12 & At baseline & $22 \%$ & 291 & $65 \%(12)$ \\
\hline $\begin{array}{l}\text { Gabbe et al. } \\
\text { (31) }\end{array}$ & Australia & $\begin{array}{l}\text { VOTOR } \\
\text { registry }\end{array}$ & Orthopedic trauma & Prospective & RTW yes/no status & 12 & $\begin{array}{l}\text { At } \\
\text { admission }\end{array}$ & $13 \%$ & 953 & $70 \%(12)$ \\
\hline Hou et al. (32) & Taiwan & Hospital & Limb trauma injury & Prospective & $\begin{array}{l}\text { "without RTW" or } \\
\text { "RTW" }\end{array}$ & $\begin{array}{l}1,3,6,12 \\
18,24\end{array}$ & NA & $0 \%$ & 1,124 & $75 \%(24)$ \\
\hline Hou et al. (33) & Taiwan & Hospital & $\begin{array}{l}\text { Traumatic limb } \\
\text { injury }\end{array}$ & Prospective & $\begin{array}{l}\text { Same or other job, } \\
\text { same workplace, } \\
\text { or other workplace }\end{array}$ & $1,6,24$ & NA & NA & 804 & $\begin{array}{l}22 \%(1) \\
50 \%(6)\end{array}$ \\
\hline $\begin{array}{l}\text { lakova et al. } \\
\text { (34) }\end{array}$ & Switzerland & Clinic & Orthopedic trauma & Prospective & $\begin{array}{l}\text { Has a job or not } \\
\text { (binary response) }\end{array}$ & 24 & $\begin{array}{l}\text { At } \\
\text { admission }\end{array}$ & $34 \%$ & 1,207 & $58 \%(24)$ \\
\hline Izadi et al. (35) & Iran & Hospital & Hand trauma & Prospective & $\begin{array}{l}\text { Time to RTW after } \\
\text { surgery }\end{array}$ & 3 & $\begin{array}{l}1-8 \text { weeks } \\
\text { after } \\
\text { surgery }\end{array}$ & NA & 280 & $46 \%(3)$ \\
\hline
\end{tabular}


TABLE 1 | Continued

\begin{tabular}{|c|c|c|c|c|c|c|c|c|c|c|}
\hline References & Country & Setting & Nature of injuries & $\begin{array}{l}\text { Study } \\
\text { design }\end{array}$ & $\begin{array}{l}\text { Outcome } \\
\text { definition }\end{array}$ & $\begin{array}{l}\text { Follow-up } \\
\text { (months) }\end{array}$ & $\begin{array}{l}\text { Predictors } \\
\text { measures }\end{array}$ & $\begin{array}{l}\text { Lost to } \\
\text { follow-up }\end{array}$ & $\begin{array}{l}\text { Number } \\
\text { in multiple } \\
\text { regression } \\
\text { analysis }\end{array}$ & $\begin{array}{l}\text { RTW rates } \\
\text { (months) }^{*}\end{array}$ \\
\hline $\begin{array}{l}\text { Kendrick et } \\
\text { al. (36) }\end{array}$ & $\begin{array}{l}\text { The } \\
\text { United Kingdom }\end{array}$ & $\begin{array}{l}\text { UK Burden } \\
\text { of Injury } \\
\text { Study }\end{array}$ & $\begin{array}{l}\text { Orthopedic trauma } \\
>80 \%\end{array}$ & Prospective & $\begin{array}{l}\text { Not being } \\
\text { prevented from } \\
\text { working for any } \\
\text { days in the last } 4 \\
\text { weeks }\end{array}$ & 1,4 & $\begin{array}{l}1-4 \text { weeks } \\
\text { after injury }\end{array}$ & $50 \%$ & 664 & $73 \%(4)$ \\
\hline $\begin{array}{l}\text { Kendrick et } \\
\text { al. (37) }\end{array}$ & $\begin{array}{l}\text { The } \\
\text { United Kingdom }\end{array}$ & Hospital & $\begin{array}{l}\text { Upper/lower } \\
\text { extremities }\end{array}$ & Prospective & $\begin{array}{l}\text { Full or part- time } \\
\text { paid employment } \\
\text { and not being } \\
\text { prevented from } \\
\text { working }\end{array}$ & $2,4,12$ & $\begin{array}{l}1 \text { month } \\
\text { postinjury }\end{array}$ & $24 \%$ & 273 & $67 \%(12)$ \\
\hline $\begin{array}{l}\text { Kimmel et al. } \\
\text { (38) }\end{array}$ & Australia & $\begin{array}{l}\text { VOTOR } \\
\text { registry }\end{array}$ & $\begin{array}{l}\text { Isolated lower limb } \\
\text { fracture }\end{array}$ & $\begin{array}{l}\text { Assessed } \\
\text { prospective }\end{array}$ & $\begin{array}{l}\text { RTW status } \\
\text { Yes/no }\end{array}$ & 12 & Preinjury & $15 \%$ & 6,775 & $84 \%(12)$ \\
\hline $\begin{array}{l}\text { Kirkeby et al. } \\
\text { (39) }\end{array}$ & Denmark & Hospital & $\begin{array}{l}\text { Wrist trauma } \\
\text { suspicion of } \\
\text { scaphoid fracture }\end{array}$ & $\begin{array}{l}\text { Retrospective } \\
\text { with } \\
\text { follow-up }\end{array}$ & $\begin{array}{l}\text { Completion of a } \\
\text { period of four } \\
\text { consecutive } \\
\text { weeks on labor } \\
\text { market }\end{array}$ & 58 & $\begin{array}{l}\text { At } \\
\text { admission }\end{array}$ & NA & 125 & NA \\
\hline $\begin{array}{l}\text { Kong et al. } \\
(40)\end{array}$ & China & Hospital & $\begin{array}{l}\text { Work-related } \\
\text { injuries }\end{array}$ & $\begin{array}{l}\text { Retrospective } \\
\text { with } \\
\text { longitudinal } \\
\text { data }\end{array}$ & $\begin{array}{l}\text { RTW sustained for } \\
3 \text { months }\end{array}$ & 8 & $\begin{array}{l}\text { At } \\
\text { admission }\end{array}$ & $25 \%$ & 335 & $78 \%(8)$ \\
\hline $\begin{array}{l}\text { Lilley et al. } \\
\text { (41) }\end{array}$ & $\begin{array}{l}\text { New } \\
\text { Zealand }\end{array}$ & $\begin{array}{l}\text { ACC claim } \\
\text { register }\end{array}$ & $\begin{array}{l}\text { Workers with } \\
\text { orthopedic trauma } \\
>75 \%\end{array}$ & Prospective & $\begin{array}{l}\text { Return to any form } \\
\text { of work }\end{array}$ & 3 & $\begin{array}{l}3 \text { months } \\
\text { postinjury }\end{array}$ & $1 \%$ & 2,250 & $73 \%(3)$ \\
\hline $\begin{array}{l}\text { Luthi et al. } \\
\text { (42) }\end{array}$ & Switzerland & Clinic & Orthopedic trauma & Prospective & $\begin{array}{l}\text { Return to same or } \\
\text { modified job }\end{array}$ & 24 & $\begin{array}{l}\text { At } \\
\text { admission }\end{array}$ & $27 \%$ & 819 & $50 \%(24)$ \\
\hline $\begin{array}{l}\text { Marom et al. } \\
\text { (43) }\end{array}$ & Israel & Clinic & Hand trauma & Prospective & $\begin{array}{l}\text { RTW status: } \\
\text { Yes/no }\end{array}$ & $3,6,9,12$ & $\begin{array}{l}\text { At } \\
\text { admission }\end{array}$ & $1 \%$ & 178 & $\begin{array}{l}32 \% \text { (3) } 65 \% \text { (6) } \\
74 \% \text { (9) } 75 \% \\
(12)\end{array}$ \\
\hline $\begin{array}{l}\text { Marom et al. } \\
\text { (44) }\end{array}$ & Israel & Clinic & Hand trauma & Prospective & $\begin{array}{l}\text { RTW status: } \\
\text { yes/no }\end{array}$ & 3 & $\begin{array}{l}\text { At } \\
\text { admission }\end{array}$ & $0 \%$ & 178 & $37 \%(3)$ \\
\hline $\begin{array}{l}\text { Murgatroyd et } \\
\text { al. (45) }\end{array}$ & Australia & Hospital & Orthopedic trauma & Prospective & $\begin{array}{l}\text { full/modified } \\
\text { duties, time from } \\
\text { injury to work }\end{array}$ & $6,12,24$ & $\begin{array}{l}2 \text { weeks } \\
\text { postinjury }\end{array}$ & $44 \%$ & 182 & $\begin{array}{l}65 \%(6), 73 \% \\
(12), 81 \%(24)\end{array}$ \\
\hline $\begin{array}{l}\text { Neutel et al. } \\
(46)\end{array}$ & Netherlands & Hospital & Hand/wrist trauma & Prospective & $\begin{array}{l}\text { Time to resume } \\
\text { work fully }\end{array}$ & 10 & $\begin{array}{l}2 \text { weeks } \\
\text { after the } \\
\text { trauma }\end{array}$ & $13 \%$ & 354 & $94 \%(10)$ \\
\hline $\begin{array}{l}\text { Roesler et al. } \\
(47)\end{array}$ & Australia & $\begin{array}{l}\text { Hand } \\
\text { therapy } \\
\text { clinic }\end{array}$ & $\begin{array}{l}\text { Traumatic hand } \\
\text { injury }\end{array}$ & $\begin{array}{l}\text { Prospective } \\
\text { follow-up }\end{array}$ & NA & 3 & $\begin{array}{l}4 \text { weeks } \\
\text { after injury }\end{array}$ & NA & 150 & NA \\
\hline
\end{tabular}




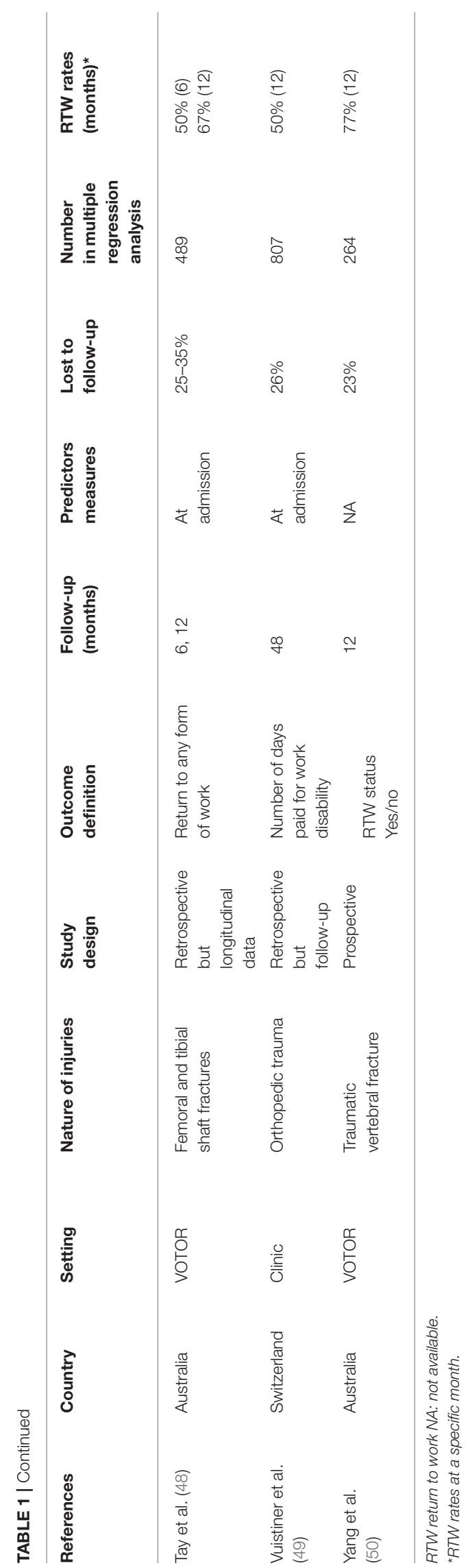

The quality of the included studies was also assessed using the NOS (Table 2). Twenty-six studies (87\%) had a total NOS score between 7 and 8 points and therefore were rated as high quality. The remaining studies were rated as having medium quality.

\section{Prognostic Factors for RTW}

The biopsychosocial factors that showed a significant association with RTW in the early and late stages are presented in Tables 3, 4, respectively.

\section{Biological Factors Early Stage}

Among the 7 biological factors, injury severity was the only factor supported by strong evidence, as it was reported in two studies with a low risk of bias and high quality (36, $47)$, in three studies with a moderate risk of bias $(24,25$, 41 ), and in one study with a high risk of bias (35). There was limited evidence for the remaining 6 factors: age (25), gender (36), body mass index (41), initial need for surgery (25), level of pain (25), and disability level postinjury $(35,44)$ (Table 3).

\section{Late Stage}

Among the 20 biological factors, age, injury severity, and level of pain were supported by strong evidence. A significant relationship between older age and delayed RTW was found in six studies $(23,27,30,32,33,42)$, and three of them were rated as high quality and had a low risk of bias $(27,32,42)$. A high level of injury severity as a barrier for RTW was identified in two studies with a low risk of bias and high quality $(27,45)$ and in six studies with a moderate risk of bias $(23,28,30,33,40,46)$. A significant relationship between a high level of pain and delayed RTW was reported in two studies with a low risk of bias and high quality $(27,43)$ and in two studies with a moderate risk of bias (34, 49). Inconsistent evidence was found for gender, as contradictory findings were reported in two studies (27, 46). There was limited evidence for the remaining 16 factors (Table 4).

\section{Psychological Factors Early Stage}

There was limited evidence for the six psychological factors: positive and negative effects (47), locus of control (47), prior depressive episode (41), quality-of-life psychological subscale (33), negative pain attitudes (25), and recovery belief (26) as predictors for RTW in the early stage (Table 3).

\section{Late Stage}

Among the 8 psychological factors, there was strong evidence for self-efficacy. The positive effect of self-efficacy on RTW has been reported in two studies with a low risk of bias and high quality $(32,43)$ and one study with a moderate risk of bias (33). Positive recovery expectations related to the better RTW outcome were supported by moderate evidence, as they were found in one study with a low risk of bias (45) and one study with a moderate risk of bias (49). 


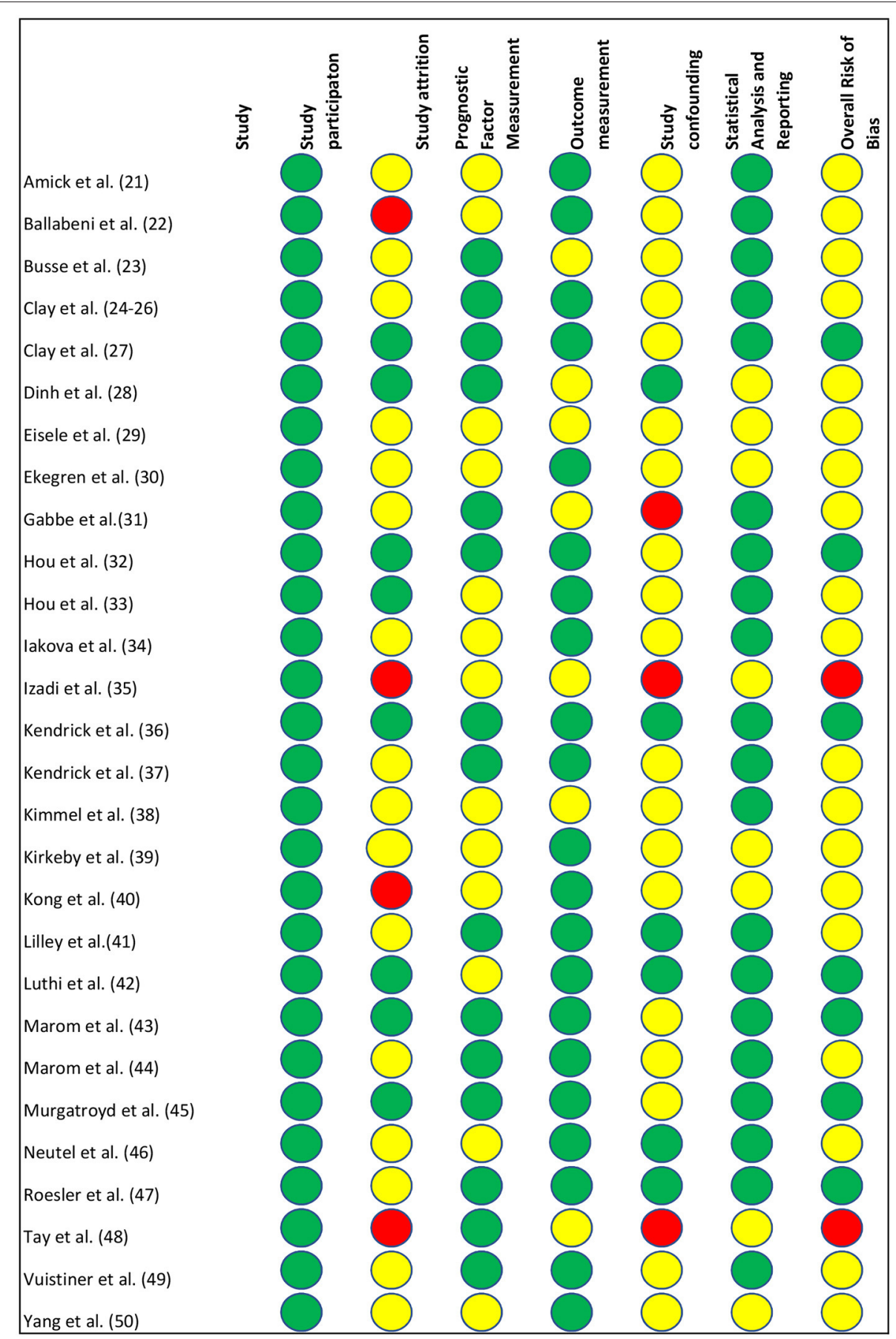

FIGURE 2 | Risk of bias according to the Quality in Prognosis Studies (QUIPS) tool. Red circle = high risk of bias, yellow circle = moderate risk of bias, green circle $=$ low risk of bias.

Depressive or anxiety symptoms $(33,37)$ and perceived severity of injury $(34,49)$ were found in two studies with a moderate risk of bias, therefore resulting in limited evidence. There was limited evidence for intrusion thoughts (43), illness beliefs (23), avoidance (34), and mental health (27) (Table 4).

\section{Social Factors}

\section{Early Stage}

Among the 20 social factors, there was limited evidence for educational level, as this factor was found in three studies with a moderate risk of bias $(26,40,44)$. Of note, limited evidence was also found that blue-collar work was related to delayed RTW 
$(25,41)$. Limited evidence was found for other factors: type of contract (41), physical work (41), perception of social support (40), received compensation (26), injured at work (36), living in deprived areas (36), etc. (Table 3).

\section{Late Stage}

There was strong evidence for blue-collar work, educational level, and compensation status related to delayed RTW. Blue-collar work as a barrier for RTW was reported in two studies with a low risk of bias and high quality $(32,45)$ and two studies with a moderate risk of bias $(33,46)$. The positive effect of high educational level on RTW outcome was found in two studies with a low risk of bias and high quality $(32,43)$ and two studies with a moderate risk of bias $(33,49)$. Compensation status has been reported in two studies with a low risk of bias and high quality $(27,43)$ and one study with a moderate risk of bias (30). There was moderate evidence for physical workload, as this factor was reported in one study with a low risk of bias and high quality (43) and three studies with a moderate risk of bias $(22,29,39)$. Other factors were supported by limited evidence (Table 4).

\section{Non-significant Factors for RTW}

Numerous BPS factors showed no association with RTW in the early and late phases (Tables 5, 6, respectively).

\section{Early Stage}

There was moderate evidence for the level of pain $(24,47)$ and self-efficacy $(44,47)$ as non-significant factors for RTW in the early phase. These factors were identified in one study with a low risk of bias and one study with a moderate risk of bias. The evidence for age $(24,35,41)$, sex $(33,41)$, and other biopsychosocial factors was limited, as they have only been identified in studies with moderate or high risk of bias.

\section{Late Stage}

There was moderate evidence for age $(37,39,45)$, gender $(23,33$, $37,39,45)$, and education $(39,42)$ as non-significant factors for RTW in the late phase. These factors were identified in one study with a low risk of bias and at least one study with a moderate risk of bias. There was limited evidence for other biopsychosocial factors (Table 6).

\section{Data Pooling}

There was variability in the definition of RTW and its measurements across the included studies, and also in the reporting of prognostic factors (age, for example, as a dichotomous or continuous variable) and the types of statistical estimates (odds ratios or hazard ratios or risk ratios). All these barriers prevented data pooling; therefore, a meta-analysis could not be performed.

\section{DISCUSSION}

In this updated systematic review of 30 studies between 2010 and 2020, we were able to extract 33 significant factors for RTW in the early phase and 46 prognostic factors in the late phase. In agreement with the previous review of 15 studies published in 2010 (9), blue-collar work and educational level were supported by strong evidence. In addition, we found strong evidence for two new factors (age and level of pain) and moderate evidence for another two new factors (physical workload and recovery expectations). Importantly, injury severity, self-efficacy, and compensation status have been upgraded from moderate evidence (9) to strong evidence in this updated review. An earlier review in 2010 (9) did not have enough evidence to support the role of older age, injury severity, level of pain, selfefficacy, recovery expectations, and physical workload as the key barriers to RTW. The identification of these new factors was in accordance with evidence of predictors from the synthesis of 56 reviews on RTW in various conditions and injuries (7). Contrary to the earlier review in 2010 (9), the role of gender on RTW was inconsistent, as contradictory results were reported in the included studies $(27,46,49)$.

The classification of predictors into early and late phase postinjury was one of the main differences between ours and the previous review (9). In the early phase following acute orthopedic trauma, strong evidence was found for injury severity only. A number of psychosocial factors, including self-efficacy, recovery expectations, blue-collar work, and physical demand, had limited evidence in the early phase but became more evident in the late phase postinjury. This is likely because while most of the injured workers return to work in a straightforward pathway soon after the acute phase, a proportion of patients might turn into the chronic work disability process. In these patients, psychosocial problems might play an important role in the late phase and interact with other factors as the key barriers to RTW. Another explanation was that the longer the duration of follow-up, the greater the likelihood of recognizing the significant effects of psychosocial problems on RTW.

Another difference was that we assessed both the significant and non-significant effects of all reported predictors. For example, increasing age showed no relationship with RTW in three studies $(37,39,45)$, but it significantly predicted RTW in the other six studies $(23,27,30,32,33,42)$. The difference might be due to selection bias. For studies demonstrating the impact of age, over half of the injured population were blue-collar or immigrant workers $(32,33,42)$. In other words, older bluecollar workers are likely to have more difficulty reentering the labor market than young white-collar workers. The predictive validity of age, therefore, must be interpreted in conjunction with the BPS context, for example, with the occupation. Careful interpretation is also needed for educational level, as this factor has shown no significant effect on RTW in two studies $(39,42)$, whereas other studies have demonstrated a significant correlation $(32,33,43,49)$. The discrepancy between these studies might be due to the different categories of predictors and duration of follow-up.

Understanding the levels of evidence of prognostic factors for postinjury employment helps to identify patients at high risk for poor RTW outcomes and to improve guidance for RTW. According to our results, injury severity was recognized as one of the principal barriers to RTW in workers; therefore, public health and work environments should pay attention to serious injury prevention, as the majority of accidents are preventable 
TABLE 2 | Quality assessment of included study based on the Newcastle-Ottawa Scale.

\begin{tabular}{|c|c|c|c|c|c|c|c|c|c|}
\hline \multirow[t]{2}{*}{ References } & \multicolumn{3}{|c|}{ Selection (score) } & \multicolumn{3}{|c|}{ Comparability (score) } & \multicolumn{3}{|c|}{ Outcome (score) } \\
\hline & $\begin{array}{l}\text { Representativeness } \\
\text { of the exposed } \\
\text { cohort }\end{array}$ & $\begin{array}{l}\text { Selection of the } \\
\text { non-exposed } \\
\text { cohort }\end{array}$ & $\begin{array}{l}\text { Ascertainment } \\
\text { of exposure }\end{array}$ & $\begin{array}{l}\text { Outcome of } \\
\text { interest was not } \\
\text { present at start } \\
\text { of study }\end{array}$ & $\begin{array}{l}\text { Based on the } \\
\text { design or } \\
\text { analysis }\end{array}$ & $\begin{array}{l}\text { Assessment of } \\
\text { outcome }\end{array}$ & $\begin{array}{l}\text { Follow-up long } \\
\text { enough for } \\
\text { outcomes to } \\
\text { occur }\end{array}$ & $\begin{array}{l}\text { Adequacy of } \\
\text { follow-up of } \\
\text { cohorts }\end{array}$ & Total score \\
\hline Amick et al. (21) & 1 & 0 & 1 & 1 & 2 & 1 & 1 & 0 & 7 \\
\hline $\begin{array}{l}\text { Ballabeni et al. } \\
\text { (22) }\end{array}$ & 1 & 0 & 1 & 1 & 2 & 1 & 1 & 0 & 7 \\
\hline Busse et al. (23) & 1 & 0 & 1 & 1 & 2 & 1 & 1 & 0 & 7 \\
\hline $\begin{array}{l}\text { Clay et al. } \\
(24-26)\end{array}$ & 1 & 0 & 1 & 1 & 2 & 1 & 1 & 0 & 7 \\
\hline Clay et al. (27) & 1 & 1 & 1 & 1 & 2 & 1 & 1 & 0 & 8 \\
\hline Dinh et al. (28) & 1 & 0 & 1 & 1 & 2 & 1 & 1 & 0 & 7 \\
\hline Eisele et al. (29) & 1 & 0 & 1 & 1 & 2 & 1 & 1 & 0 & 7 \\
\hline $\begin{array}{l}\text { Ekegren et al. } \\
\text { (30) }\end{array}$ & 1 & 1 & 1 & 1 & 1 & 1 & 1 & 0 & 7 \\
\hline Gabbe et al. (31) & 1 & 0 & 1 & 1 & 1 & 1 & 1 & 0 & 6 \\
\hline Hou et al. (32) & 1 & 0 & 1 & 1 & 2 & 1 & 1 & 1 & 8 \\
\hline Hou et al. (33) & 1 & 1 & 1 & 1 & 2 & 1 & 1 & 0 & 8 \\
\hline lakova et al. (34) & 1 & 0 & 1 & 1 & 2 & 1 & 1 & 1 & 8 \\
\hline Izadi et al. (35) & 1 & 0 & 1 & 0 & 1 & 1 & 1 & 0 & 5 \\
\hline $\begin{array}{l}\text { Kendrick et al. } \\
\text { (36) }\end{array}$ & 1 & 1 & 1 & 1 & 2 & 1 & 1 & 0 & 8 \\
\hline $\begin{array}{l}\text { Kendrick et al. } \\
\text { (37) }\end{array}$ & 1 & 0 & 1 & 1 & 2 & 1 & 1 & 0 & 7 \\
\hline $\begin{array}{l}\text { Kimmel et al. } \\
\text { (38) }\end{array}$ & 1 & 1 & 1 & 1 & 1 & 1 & 1 & 0 & 7 \\
\hline $\begin{array}{l}\text { Kirkeby et al. } \\
\text { (39) }\end{array}$ & 1 & 0 & 1 & 1 & 1 & 1 & 1 & 0 & 6 \\
\hline Kong et al. (40) & 1 & 0 & 1 & 1 & 2 & 1 & 1 & 0 & 7 \\
\hline Lilley et al. (41) & 1 & 0 & 1 & 1 & 2 & 1 & 1 & 0 & 7 \\
\hline Luthi et al. (42) & 1 & 1 & 1 & 1 & 2 & 1 & 1 & 0 & 8 \\
\hline Marom et al. (43) & 1 & 0 & 1 & 1 & 2 & 1 & 1 & 1 & 8 \\
\hline Marom et al. (44) & 1 & 0 & 1 & 1 & 1 & 1 & 1 & 1 & 7 \\
\hline $\begin{array}{l}\text { Murgatroyd et al. } \\
\text { (45) }\end{array}$ & 1 & 0 & 1 & 1 & 2 & 1 & 1 & 1 & 8 \\
\hline Neutel et al. (46) & 1 & 0 & 1 & 1 & 2 & 1 & 1 & 1 & 8 \\
\hline $\begin{array}{l}\text { Roesler et al. } \\
\text { (47) }\end{array}$ & 1 & 0 & 1 & 1 & 2 & 1 & 1 & 0 & 7 \\
\hline Tay et al. (48) & 1 & 0 & 1 & 1 & 1 & 1 & 1 & 0 & 6 \\
\hline $\begin{array}{l}\text { Vuistiner et al. } \\
\text { (49) }\end{array}$ & 1 & 0 & 1 & 1 & 2 & 1 & 1 & 0 & 7 \\
\hline Yang et al. (50) & 1 & 0 & 1 & 1 & 2 & 1 & 1 & 1 & 8 \\
\hline
\end{tabular}


TABLE 3 | Barriers and facilitators for RTW in the early phase ( $\leq 6$ months) postinjury.

\begin{tabular}{|c|c|c|c|c|c|c|}
\hline Factors & Authors & Categories of interest & Barriers for RTW* & $\begin{array}{c}\text { Facilitators for } \\
\text { RTW* }\end{array}$ & $\begin{array}{l}\text { Statistical } \\
\text { reported }\end{array}$ & $\begin{array}{l}\text { Levels of } \\
\text { evidence }\end{array}$ \\
\hline \multicolumn{7}{|c|}{ Biological factors $(n=7)$} \\
\hline \multirow[t]{6}{*}{ Injury severity } & Izadi et al. (35) & Modified hand injury severity scale & $11.45(6.88-16.02)$ & & Coef $(95 \% \mathrm{Cl})$ & Strong \\
\hline & Roesler et al. (47) & Modified hand injury severity scale & 1.66 & & OR & \\
\hline & Kendrick et al. (36) & Abbreviated injury scale & $0.79(0.68-0.92)$ & & RR (95\% Cl) & \\
\hline & Lilley et al. (41) & Hospital admission for injury & $2.10(1.66-2.64)$ & & OR $(95 \% \mathrm{Cl})$ & \\
\hline & Clay et al. (24) & Isolated vs. Mutiple injury & & $2.80(1.10-6.97)$ & OR $(95 \% \mathrm{Cl})$ & \\
\hline & Clay et al. (25) & Injury Severity Scores > 9 & $0.63(0.39-0.99)$ & & $\operatorname{RRR}(95 \% \mathrm{Cl})$ & \\
\hline \multirow[t]{2}{*}{ Disability post-injury } & Marom et al. (44) & WHO-DAS II & $0.96(0.93-0.99)$ & & OR $(95 \% \mathrm{Cl})$ & Limited \\
\hline & Izadi et al. (35) & Work DASH & $0.60(0.32-0.88)$ & & Coef $(95 \% \mathrm{Cl})$ & \\
\hline \multicolumn{7}{|l|}{ Other factors } \\
\hline & Kendrick et al. (36) & Male vs. female & & $1.94(1.34-2.82)$ & RR (95\% Cl) & Limited \\
\hline & Lilley et al. (41) & BMI (Obese vs. normal) & $1.48(1.13-1.94)$ & & OR $(95 \% \mathrm{Cl})$ & Limited \\
\hline & Clay et al. (25) & Increasing age & $0.98(0.96-0.99)$ & & $\operatorname{RRR}(95 \% \mathrm{Cl})$ & Limited \\
\hline & Clay et al. (25) & McGill Pain Questionnaire & $0.47(0.27-0.82)$ & & $\operatorname{RRR}(95 \% \mathrm{Cl})$ & Limited \\
\hline & Clay et al. (25) & Initial need for surgery & $0.61(0.39-0.96)$ & & $\operatorname{RRR}(95 \% \mathrm{Cl})$ & Limited \\
\hline \multicolumn{7}{|c|}{ Psychological factors $(n=6)$} \\
\hline \multirow[t]{6}{*}{ Other factors } & Roesler et al. (47) & Positive and negative affect scale & 1.14 & & OR & Limited \\
\hline & Roesler et al. (47) & Health locus of control & 5.11 & & OR & Limited \\
\hline & Lilley et al. (41) & Prior depressive episode & $1.27(1.02-1.59)$ & & OR $(95 \% \mathrm{Cl})$ & Limited \\
\hline & Hou et al. (33) & Psychological subscale & $1.15(1.01-1.30)$ & & OR $(95 \% \mathrm{Cl})$ & Limited \\
\hline & Clay et al. (25) & Negative pain attitudes & $0.49(0.31-0.77)$ & & $\operatorname{RRR}(95 \% \mathrm{Cl})$ & Limited \\
\hline & Clay et al. (26) & Recovery belief, strong & & $\begin{array}{c}16.73 \\
(3.59-77.88)\end{array}$ & OR $(95 \% \mathrm{Cl})$ & Limited \\
\hline \multicolumn{7}{|c|}{ Social factors $(n=20)$} \\
\hline \multirow[t]{3}{*}{ Education } & Marom et al. (44) & Education $\geq 12$ years & & $3.44(1.35-8.73)$ & OR (95\% Cl) & Limited \\
\hline & Kong et al. (40) & Secondary vs. primary school & & $2.5(1.3-4.9)$ & $\mathrm{HR}(95 \% \mathrm{Cl})$ & \\
\hline & Clay et al. (26) & University & & $6.27(1.72-22.9)$ & OR $(95 \% \mathrm{Cl})$ & \\
\hline \multirow[t]{2}{*}{ Blue-collar work } & Lilley et al. (41) & Blue-collar vs. white-collar & $1.52(1.14-2.02)$ & & OR $(95 \% \mathrm{Cl})$ & Limited \\
\hline & Clay et al. (25) & Blue-collar vs. white-collar & $0.52(0.32-0.84)$ & & $\operatorname{RRR}(95 \% \mathrm{Cl})$ & \\
\hline \multirow[t]{18}{*}{ Other factors } & Marom et al. (44) & Use of legal counsel (yes) & $0.45(0.20-1.00)$ & & OR $(95 \% \mathrm{Cl})$ & Limited \\
\hline & Izadi et al. (35) & Smoker & $7.91(1.41-14.41)$ & & Coef $(95 \% \mathrm{Cl})$ & Limited \\
\hline & Izadi et al. (35) & Job title & & & Coef $(95 \% \mathrm{Cl})$ & Limited \\
\hline & Roesler et al. (47) & Number of people in houshold & & 0.015 & OR & Limited \\
\hline & Kendrick et al. (36) & Injured at work (yes vs. no) & $0.49(0.27-0.87)$ & & RR (95\% Cl) & Limited \\
\hline & Lilley et al. (41) & Temporary vs. permanent contract & $1.89(1.27-2.81)$ & & OR $(95 \% \mathrm{Cl})$ & Limited \\
\hline & Kendrick et al. (36) & Self employed vs. paid employment & & $1.15(1.03-1.30)$ & RR $(95 \% \mathrm{Cl})$ & Limited \\
\hline & Lilley et al. (41) & $6-7$ vs. 5 days & $1.54(1.21-1.96)$ & & OR $(95 \% \mathrm{Cl})$ & Limited \\
\hline & Lilley et al. (41) & Physial work & $1.93(1.38-2.72)$ & & OR $(95 \% \mathrm{Cl})$ & Limited \\
\hline & Kendrick et al. (36) & Living in deprived areas & $0.59(0.40-0.85)$ & & RR (95\% Cl) & Limited \\
\hline & Lilley et al. (41) & Income (<30.000 vs. >5000 USD) & $1.81(1.33-2.48)$ & & OR $(95 \% \mathrm{Cl})$ & Limited \\
\hline & Lilley et al. (41) & Financial security (insecure) & $1.55(1.22-1.96)$ & & OR $(95 \% \mathrm{Cl})$ & Limited \\
\hline & Lilley et al. (41) & Exercise (7 days vs. $\leq 4$ days) & & $0.67(0.54-0.83)$ & OR $(95 \% \mathrm{Cl})$ & Limited \\
\hline & Kong et al. (40) & Family's attituted to RTW & & $4.0(1.4-11)$ & $\mathrm{HR}(95 \% \mathrm{Cl})$ & Limited \\
\hline & Kong et al. (40) & Perception of social support & & $1.9(1.2-3.0)$ & $\mathrm{HR}(95 \% \mathrm{Cl})$ & Limited \\
\hline & Kong et al. (40) & Computer skill training (yes) & & $1.5(1.1-2.1)$ & $\mathrm{HR}(95 \% \mathrm{Cl})$ & Limited \\
\hline & Clay et al. (25) & Social functioning (SF36) & & $1.89(1.17-3.07)$ & $\mathrm{RRR}(95 \% \mathrm{Cl})$ & Limited \\
\hline & Clay et al. (26) & Received compensation & $0.23(0.09-0.61)$ & & OR $(95 \% \mathrm{Cl})$ & Limited \\
\hline
\end{tabular}

$R T W$, Return to work; OR, odds ratio; $R R$, relative risk; Coef, coefficient; HR, Hazard ratio; RRR, relative rate ratio; Cl, confidence interval.

*Barriers or facilitators for RTW were reported in positive or negative direction depending on the definition of outcome, or the categories of interest, or the statistical reported.

Studies with a low risk of bias and high-quality were bolded. 
TABLE 4A | Barriers and facilitators for RTW in the late phase (> 6 months) postinjury (part 1).

\begin{tabular}{|c|c|c|c|c|c|c|}
\hline Factors & Authors & Categories of interest & Barriers for RTW* & Facilitators for RTW* & Statistical reported & $\begin{array}{l}\text { Levels of } \\
\text { evidence }\end{array}$ \\
\hline \multicolumn{7}{|c|}{ Biological factors $(n=20)$} \\
\hline \multirow[t]{6}{*}{ Age } & Ekegren et al. (30) & 55-64 vs. $16-24$ & $0.11(0.03-0.40)$ & & OR $(95 \% \mathrm{Cl})$ & Strong \\
\hline & Hou et al. (32) & Age $>65$ vs. $<65$ & $0.28(p<0.001)$ & & coef & \\
\hline & Luthi et al. (42) & Inscreasing age, per 10 years & 1.19 (1.07-1.34) & & OR $(95 \% \mathrm{Cl})$ & \\
\hline & Busse et al. (23) & Increasing age, per 10 years & $0.74(0.33-1.69)$ & & OR $(95 \% \mathrm{Cl})$ & \\
\hline & Hou et al. (33) & Increasing age & $1.04(1.01-1.06)$ & & OR $(95 \% \mathrm{Cl})$ & \\
\hline & Clay et al. (27) & Increasing age & $0.97(0.96-0.99)$ & & HR (95\% Cl) & \\
\hline \multirow[t]{8}{*}{ Injury severity } & Neutel et al. (46) & presence of complication & $1.88(1.04-3.42)$ & & $\mathrm{HR}(95 \% \mathrm{Cl})$ & Strong \\
\hline & Ekegren et al. (30) & Isolated vs. non-isolated injury & $0.31(0.15-0.64)$ & & OR $(95 \% \mathrm{Cl})$ & \\
\hline & Murgatroyd et al. (45) & New injury severity score & $0.54(0.35-0.82)$ & & HR (95\% Cl) & \\
\hline & Dinh et al. (28) & Injury severity score & $0.98(0.97-0.99)$ & & OR $(95 \% \mathrm{Cl})$ & \\
\hline & Busse et al. (23) & Multi vs. no multi trauma & $0.44(0.18-0.74)$ & & OR (95\% Cl) & \\
\hline & Kong et al. (40) & Least serious to serious & & $3.5(2.0-6.0)$ & $\mathrm{HR}(95 \% \mathrm{Cl})$ & \\
\hline & Hou et al. (33) & Hospitalization days & $1.18(1.1-0.25)$ & & OR $(95 \% \mathrm{Cl})$ & \\
\hline & Clay et al. (27) & Severe vs. minor/moderate & $0.41(0.26-0.66)$ & & HR (95\% Cl) & \\
\hline \multirow[t]{6}{*}{ Pain level } & Marom et al. (43) & Visual analog scale & $0.91(0.85-0.98$ & & HR (95\% Cl) & Strong \\
\hline & Vuistiner et al. (49) & Brief pain inventory & $0.67(0.59-0.76)$ & & $\mathrm{HR}(95 \% \mathrm{Cl})$ & \\
\hline & Vuistiner et al. (49) & Pain decrease & & $1.46(1.3-1.64)$ & HR (95\% Cl) & \\
\hline & Clay et al. (27) & Symptomatic pain & $0.47(0.30-0.75)$ & & HR (95\% Cl) & \\
\hline & lakova et al. (34) & Visual analog scale & 0.59 (0.59-0.59) & & OR $(95 \% \mathrm{Cl})$ & \\
\hline & lakova et al. (34) & Pain decrease & & $1.69(1.47-2.04)$ & OR $(95 \% \mathrm{Cl})$ & \\
\hline \multirow[t]{3}{*}{ Gender } & Neutel et al. (46) & Female vs. Male & $1.61(1.22-2.12)$ & & HR (95\% Cl) & Inconsistent \\
\hline & Clay et al. (27) & Female vs. Male & & $2.05(1.22-3.46)$ & HR (95\% Cl) & \\
\hline & Vuistiner et al. (49) & Female vs. Male & & $1.29(1.14-1.47)$ & $\mathrm{HR}(95 \% \mathrm{Cl})$ & \\
\hline \multirow[t]{17}{*}{ Other factors } & Kimmel et al. (38) & Discharge to rehabilitation & & $0.34(0.26-0.46)$ & OR $(95 \% \mathrm{Cl})$ & Limited \\
\hline & Marom et al. (43) & Post-injury disability & $0.98(0.97-0.99)$ & & HR(95\% Cl) & Limited \\
\hline & Neutel et al. (46) & Diagnosis other than wrist pain & $2.48(1.63-3.76)$ & & $\mathrm{HR}(95 \% \mathrm{Cl})$ & Limited \\
\hline & Eisele et al. (29) & Joint functions & & $1.63(1.17-2.26)$ & $\mathrm{HR}(95 \% \mathrm{Cl})$ & Limited \\
\hline & Eisele et al. (29) & Sensory funtions & & $2.33(1.45-3.74)$ & $\mathrm{HR}(95 \% \mathrm{Cl})$ & Limited \\
\hline & Kirkeby et al. (39) & MRI findings (yes) & $0.48(0.29-0.80)$ & & $\mathrm{HR}(95 \% \mathrm{Cl})$ & Limited \\
\hline & Kendrick et al. (37) & Increased hospital stay & $0.91(0.86-0.96)$ & & OR $(95 \% \mathrm{Cl})$ & Limited \\
\hline & Ekegren et al. (30) & Pre-injury disability & $0.21(0.07-0.60)$ & & OR (95\% Cl) & Limited \\
\hline & Murgatroyd et al. (45) & Never smoked & & $1.54(1.04-2.23)$ & HR (95\% Cl) & Limited \\
\hline & Murgatroyd et al. (45) & Pre-injury health status & $0.36(0.14-0.91)$ & & HR (95\% Cl) & Limited \\
\hline & Hou et al. (32) & lower limbs vs. upper limbs & $0.29(p<0.001)$ & & coef & Limited \\
\hline & Vuistiner et al. (49) & EuroQol-5D & $1.16(1.13-1.19)$ & & $\mathrm{HR}(95 \% \mathrm{Cl})$ & Limited \\
\hline & Tay et al. (48) & Delayed union in fracture limb & $0.76(0.57-0.94)$ & & $\mathrm{RR}(95 \% \mathrm{Cl})$ & Limited \\
\hline & Busse et al. (23) & Open vs. close fracture & $0.36(0.18-0.74)$ & & OR $(95 \% \mathrm{Cl})$ & Limited \\
\hline & Hou et al. (33) & Lower limb vs. upper limb & $3.63(2.00-6.60)$ & & OR (95\% Cl) & Limited \\
\hline & Yang et al. (50) & Burst fracture vs. no burst & $0.46(0.22-0.97)$ & & OR (95\% Cl) & Limited \\
\hline & Yang et al. (50) & Radius vs. no radius fracture & $0.12(0.03-0.43)$ & & OR $(95 \% \mathrm{Cl})$ & Limited \\
\hline
\end{tabular}

RTW, Return to work; OR, odds ratio; $R R$, relative risk; Coef, coefficient; HR, Hazard ratio; Cl, confidence interval.

${ }^{*}$ Barriers or facilitators for RTW were reported in positive or negative direction depending on the definition of outcome, the categories of interest, and the statistical reported. Studies with a low risk of bias and high-quality were bolded.

(51). Whereas, the prevalence of workplace injuries seemed to be reduced from 2010 to 2018 in Europe thanks to the European strategic framework on health and safety at work (52), the prevalence of non-work injuries (domestic, road, and leisure time injuries) remained high. Public health should take action to improve road safety legislation, road infrastructure, and first trauma care as core measures for reducing the burden of road accidents. Prevention campaigns for other injury causes, especially sports injuries, are necessary as well.

Older injured workers might need special promoting policies to enhance RTW, especially blue-collar workers, including adapting work accommodations. In addition, providing access 
TABLE 4B | Barriers and facilitators for RTW in the late phase (> 6 months) postinjury (part 2).

\begin{tabular}{|c|c|c|c|c|c|c|}
\hline Factors & Authors & Categorgies of interest & Barriers for $\mathrm{RTW}^{*}$ & Facilitators for RTW* & Statistical reported & Levels of evidence \\
\hline \multicolumn{7}{|c|}{ Psychological factors $(n=8)$} \\
\hline \multirow[t]{3}{*}{ Self efficacy } & Marom et al. (43) & Decreased level & $1.34(1.10-1.64)$ & & HR $(95 \% \mathrm{Cl})$ & Strong \\
\hline & Hou et al. (32) & High vs. no chance & & $0.352(p<0.001)$ & coef & \\
\hline & Hou et al. (33) & High vs. no chance & & $0.20(0.09-0.47)$ & OR (95\% Cl) & \\
\hline \multirow[t]{2}{*}{ Recovery expectation } & Murgatroyd et al. (45) & Recovery expectations & & $2.09(1.50-2.94)$ & HR (95\% Cl) & Moderate \\
\hline & Vuistiner et al. (49) & Positive expectation & & $1.50(1.32-1.70)$ & HR (95\% Cl) & \\
\hline \multirow[t]{2}{*}{ Depressive/Anxiety } & Kendrick et al. (37) & Depression & $0.87(0.79-0.95)$ & & OR (95\% Cl) & Limited \\
\hline & Hou et al. (33) & Depressive symptoms & $1.11(1.03-1.20)$ & & OR $(95 \% \mathrm{Cl})$ & \\
\hline \multirow[t]{2}{*}{ Perception of injury } & Vuistiner et al. (49) & High perceived & $0.72(0.61-0.85)$ & & $\mathrm{HR}(95 \% \mathrm{Cl})$ & Limited \\
\hline & lakova et al. (34) & Low perceived & & $1.08(1.03-1.14)$ & OR (95\% Cl) & \\
\hline \multirow[t]{4}{*}{ Other factors $(n=4)$} & Marom et al. (43) & Intrusion thoughts & $0.70(0.57-0.86)$ & & HR $(95 \% \mathrm{Cl})$ & Limited \\
\hline & Busse et al. (23) & illness beliefs & $0.60(0.50-0.73)$ & & OR $(95 \% \mathrm{Cl})$ & Limited \\
\hline & lakova et al. (34) & lower avoidance & & $0.69(0.61-0.79)$ & OR (95\% Cl) & Limited \\
\hline & Clay et al. (27) & Mental health (Poor vs. good) & $0.57(0.35-0.91)$ & & HR (95\% Cl) & Limited \\
\hline \multicolumn{7}{|l|}{ Social factors $(n=18)$} \\
\hline \multirow[t]{4}{*}{ Blue-collar work } & Neutel et al. (46) & Blue-collar vs. white-collar & $2.52(1.89-3.37)$ & & HR (95\% Cl) & Strong \\
\hline & Murgatroyd et al. (45) & Manual workers vs. white-collar & $0.53(0.43-0.83)$ & & HR (95\% Cl) & \\
\hline & Hou et al. (32) & Blue-collar vs. white-collar & $0.14(p=0.04)$ & & coef & \\
\hline & Hou et al. (33) & Workers vs. white-collar & $2.24(1.12-4.48)$ & & OR (95\% Cl) & \\
\hline \multirow[t]{4}{*}{ Education } & Marom et al. (43) & $\leq 12$ vs. $>12$ years & $1.56(0.97-2.52)$ & & HR (95\% Cl) & Strong \\
\hline & Hou et al. (32) & $>12$ vs. $<9$ years & & $0.41(p<0.001)$ & coef & \\
\hline & Hou et al. (33) & $>12$ vs. $<9$ years & & $0.21(0.09-0.50)$ & OR (95\% Cl) & \\
\hline & Vuistiner et al. (49) & High education & & $1.26(1.09-1.46)$ & $\mathrm{HR}(95 \% \mathrm{Cl})$ & \\
\hline \multirow[t]{3}{*}{ Compensable status } & Marom et al. (43) & Recognized for benefit claim & $0.88(1.42-1.83)$ & & HR (95\% Cl) & Strong \\
\hline & Ekegren et al. (30) & Private/Worksale vs. Medicare & $0.33(0.16-0.70)$ & & OR (95\% Cl) & \\
\hline & Clay et al. (27) & No compensation & & $2.05(1.20-3.49)$ & HR (95\% Cl) & \\
\hline \multirow[t]{4}{*}{ Workload } & Marom et al. (43) & Workload/job control & $0.58(0.40-0.83)$ & & HR $(95 \%$ Cl) & Moderate \\
\hline & Kirkeby et al. (39) & Forceful work & $0.55(0.30-0.99)$ & & HR $(95 \% \mathrm{Cl})$ & \\
\hline & Eisele et al. (29) & Low hand strain at work & & $2.33(1.45-3.74)$ & $\mathrm{HR}(95 \% \mathrm{Cl})$ & \\
\hline & Ballabeni et al. (22) & High job strain & $3.79(1.54-9.31)$ & & OR (95\% Cl) & \\
\hline \multirow[t]{14}{*}{ Other factors $(n=14)$} & Marom et al. (43) & Legal counsel (yes vs. no) & $0.53(0.34-0.82)$ & & HR (95\% Cl) & Limited \\
\hline & Neutel et al. (46) & Blame someone else for injury & $1.70(1.11-2.59$ & & $\mathrm{HR}(95 \% \mathrm{Cl})$ & Limited \\
\hline & Eisele et al. (29) & Self employed vs. full time & & $1.77(1.13-2.76)$ & $\mathrm{HR}(95 \% \mathrm{Cl})$ & Limited \\
\hline & Amick et al. (21) & Organizational policies & & $2.07(1.18-3.62)$ & OR $(95 \% \mathrm{Cl})$ & Limited \\
\hline & Kendrick et al. (37) & Threatening life event & $0.27(0.10-0.72)$ & & OR (95\% Cl) & Limited \\
\hline & Murgatroyd et al. (45) & Full time vs. part-time & & $1.99(1.26-3.14)$ & HR (95\% Cl) & Limited \\
\hline & Gabbe et al. (31) & Not at fault & & $0.92(0.86-0.99)$ & $\mathrm{RR}(95 \% \mathrm{Cl})$ & Limited \\
\hline & Luthi et al. (42) & Speak local language & & $0.67(0.51-0.88)$ & OR (95\% Cl) & Limited \\
\hline & Luthi et al. (42) & Restriction in integration & $1.42(1.24-1.61)$ & & OR $(95 \% \mathrm{Cl})$ & Limited \\
\hline & Kong et al. (40) & Perception of social support & & $1.9(1.2-3.0)$ & $\mathrm{HR}(95 \% \mathrm{Cl})$ & Limited \\
\hline & Kong et al. (40) & Family's attituted to RTW & & $4.0(1.4-11)$ & HR (95\% Cl) & Limited \\
\hline & Kong et al. (40) & Computer skill training (yes) & & $1.5(1.1-2.1)$ & $\operatorname{HR}(95 \% \mathrm{Cl})$ & Limited \\
\hline & Hou et al. (33) & Disturbance in daily life & $2.10(1.02-4.30)$ & & OR $(95 \% \mathrm{Cl})$ & Limited \\
\hline & Hou et al. (33) & Married vs. others & & $0.50(0.27-0.93)$ & OR (95\% Cl) & Limited \\
\hline
\end{tabular}

RTW, Return to work; OR, odds ratio; RR, relative risk; Coef, coefficient; HR, Hazard ratio; $\mathrm{Cl}$, confidence interval.

*Barriers or facilitators for RTW were reported in positive or negative direction depending on the definition of outcome, the categories of interest, and the statistical reported.

Studies with a low risk of bias and high quality were bolded. 
TABLE 5 | Non-significant factors for RTW in the early phase ( $\leq 6$ months) postinjury.

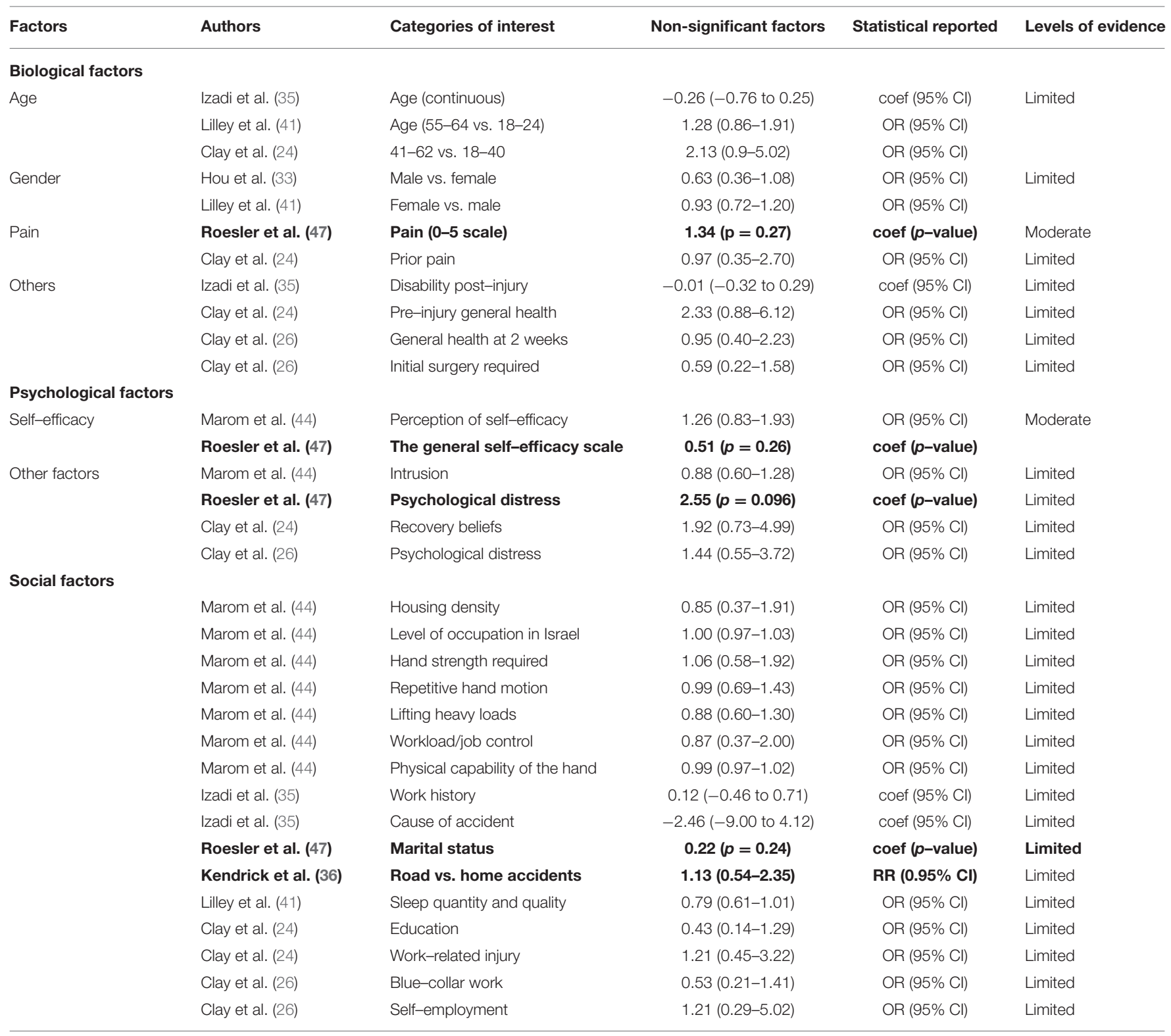

$O R$, Odds ratio; $R R$, relative risk; Coef, coefficient; $\mathrm{Cl}$, confidence interval.

Studies with a low risk of bias and high quality were bolded.

to interdisciplinary treatment for pain is also of importance. Health professionals, however, should remain mindful that nonbiological factors such as self-efficacy, recovery expectations, blue-collar work, and physical workload also contribute significantly to the RTW outcome. Adapting physical workload, for example, offering lighter or modified or graded work exposure or performing onsite work evaluation, may help to increase the success of RTW. Our findings support the "seven principles for successful RTW" previously established for enhancing RTW in musculoskeletal or pain-related conditions (53-55). It is also suggested that self-efficacy and recovery expectations are relevant factors that need to be screened in workers as early as possible after injury. Higher self-efficacy and recovery expectations can be obtained by support from leaders and coworkers to promote RTW (56). Surprisingly, work-related factors such as support from leaders and coworkers were not reported in the included studies. Hopefully, future researchers will strive to improve reporting on this factor.

Worker compensation has been supported in our updated review by strong evidence. However, workers' compensation systems are different from country to country, and the interpretation of this finding needs to be cautious. For example, most European countries compensate workers for both professional and non-professional accidents, and coverage 
TABLE 6 | Non-significant factors for RTW in the late phase (> 6 month) postinjury.

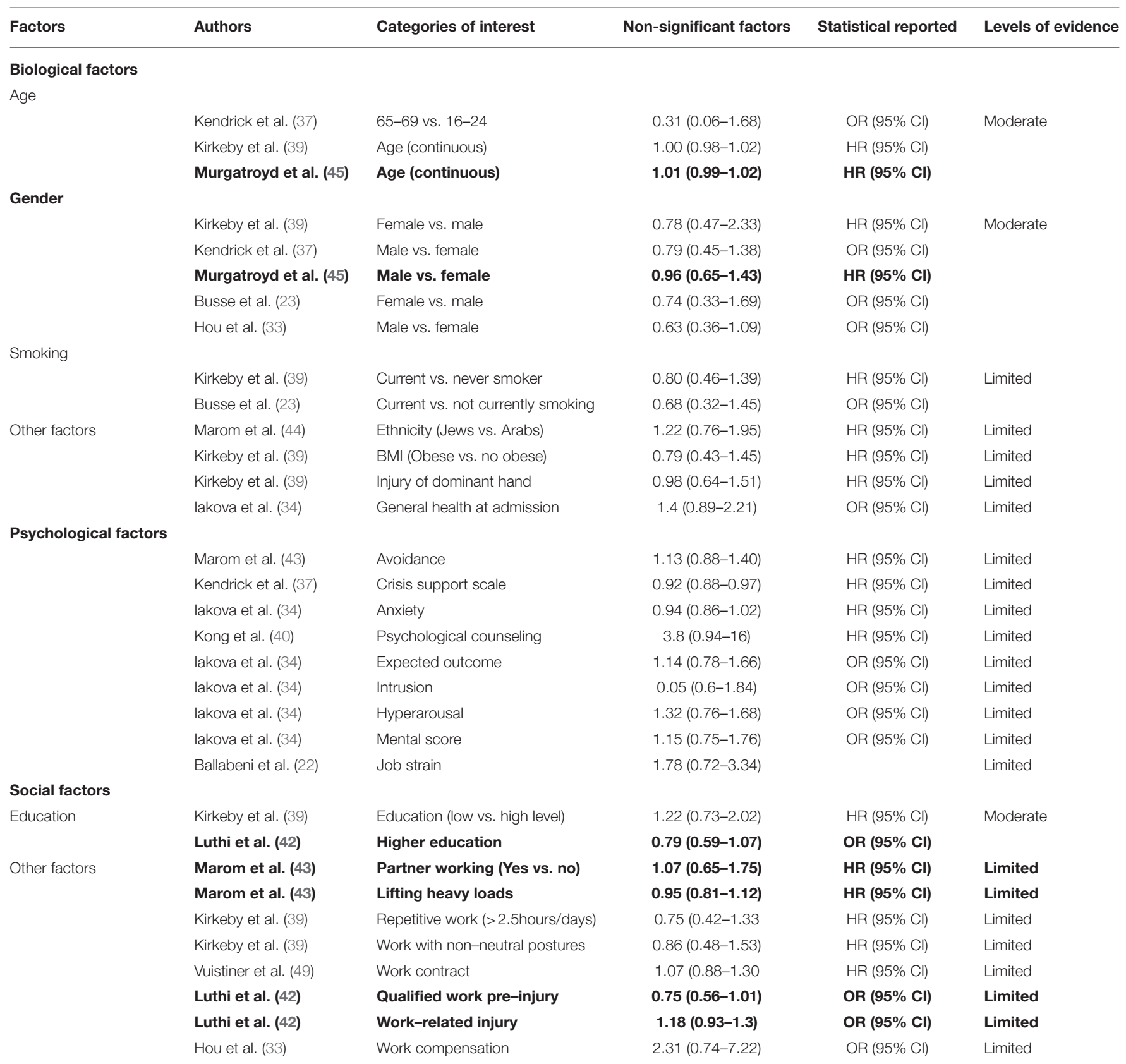

OR, Odds- ratio; HR, Hazard ratio; Cl, confidence interval; BMI, body mass index.

Studies with a low risk of bias and high-quality were bolded.

is provided regardless of fault. Another important issue of concern in workers' compensation is the source of insurance. In many European countries, public organizations control workers' compensation insurance policies, whereas in some countries (for example, Australia, UK), insurance can be provided either directly through the employer or through a private insurance provider. The negative impact of compensation on RTW was reported in countries where private insurance companies were involved in the sick pay scheme $(27,30,43)$. Workers' compensation status was not related to RTW in Taiwan (33), where the public labor system pays injured workers their lost wages for 2 years postinjury.

It should be noted that other factors (depression, psychological disorders, social support, vocational training, etc.) were rated as limited evidence in the early and late phases because the number of high-quality studies required for qualification has not been reached. They should not be interpreted as factors of limited importance. These factors may 
need to be addressed in further high-quality studies to determine whether they are relevant in the RTW process after orthopedic trauma. Many of these factors are potentially amenable to intervention. For example, psychological disorders may benefit from psychological care or cognitive behavioral therapy; computer skills can be acquired from vocational training.

From the methodological point of view, the inclusion and exclusion criteria were quite similar between ours and the previous review (inclusion of longitudinal studies of patients sustaining orthopedic trauma, and exclusion of studies that did not recognize the multifactorial nature of RTW) (9). Unlike the specific criteria applied in the previous review (9), we used the QUIPS, a recently validated tool, to assess the risk of bias of all included studies. For one study presenting the predictive model (42), the risk of bias was also assessed by PROBAST, which resulted in the same level of risk of bias. We found that study attribution and confounding were the most common types of bias risk. Some contributing studies did not clearly describe the rates of loss to follow-up or the potential impact of subjects lost to follow-up $(33,35,39)$, which are important elements affecting study attribution. The methods for missing data have not been appropriately handled in some studies $(31,34,50)$, resulting in a source of reduced statistical power. Apart from the assessment of the risk of bias, the quality of all included cohorts was also evaluated by the NOS. It was demonstrated that all seven studies with a low risk of bias were rated as having high quality. Two studies with a high risk of bias were rated as having medium quality. The remaining 11 studies of moderate risk of bias were rated as having high quality in nine studies and medium quality in two studies.

There has been a lack of consistency in the definition of the RTW outcome, as it can be defined as sustained RTW, fitness to work, or simply yes/no status. Likewise, the prognostic factors were measured in different ways (even for age: continuously and dichotomously) at different time points after the traumatic event. It should be noted that until present, most of the included studies were predicting factor studies that focus only on the associative relationship between prognostic factors and RTW outcome. Studies evaluating the predictive model's performance, for example, the external validation of the model, remain limited.

\section{Strengths and Limitations}

The strengths of this review are as follows: First, this review was conducted following the PRISMA recommendations for systematic reviews (15). The high number of included studies $(n=30)$ and the clear predefined inclusion criteria (cohort studies with longitudinal data on RTW, and only results from multiple regression models were considered) allowed us to establish robust conclusions about the validity of predictors. In addition, to provide an objective evaluation, all enrolled studies were independently assessed by the two reviewers. The quality and risk of bias were evaluated by validated tools recommended by the Cochrane Methods Prognosis group (57). The levels of evidence of biopsychosocial factors were made based on the high quality and low risk of bias studies.
This review also has some limitations. First, we could not regroup relevant prognostic factors in a meta-analysis due to variability in the definitions and measurements of the outcomes and predictors. Second, the quality and risk of bias tools involved a degree of subjectivity; however, this was solved by careful discussion. Third, the exclusion of studies of nonorthopedic injuries (for example, traumatic brain injury or internal organ injury) prevents the generalization of findings to other injuries. Last, to avoid the overlooking of evidence, the inclusion criteria (prospective studies, sample size $>80$ participants) may have resulted in the exclusion of potentially relevant studies.

\section{Suggestions for Improvement of Research in This Area}

The definition of RTW remains inconsistent, and further consensus on its definition is needed. Recently, some RTW questionnaires have been developed to measure the different aspects of RTW in patients with work-related injury $(58,59)$. These new questionnaires might be used in the future to assess the multiple dimensions of RTW outcomes. Likewise, some prognostic factors need to be measured or categorized uniformly (for example, age as a continuous variable) to ensure that data pooling can be performed. Moreover, the majority of predicting factor studies were at the developing stage, without validating performance in new patients. We suppose that validating and studying the clinical impact of a prediction model RTW rather than the usual reporting of predictive values could help to guide an efficient strategy. To improve the quality of studies and reduce the risk of bias, it is necessary to report the rate of loss to followup and to provide appropriate statistical methods for missing data in the study. There is also a gap in the literature regarding the effects of analgesic prescriptions (especially opioids) and work-related factors such as support from leaders and coworkers on RTW after acute orthopedic trauma. It would be useful to conduct further research on these factors to acknowledge their roles in the RTW process. None of the included articles in this review originated from middle- or low-income countries, and there is a need to know the situation in these countries as well.

\section{CONCLUSION}

In this updated systematic review of 30 studies between 2010 and 2020, injury severity was identified as a key barrier for RTW in the early and late phases postorthopedic injury. In the late phase postinjury, there was strong evidence for age, level of pain, selfefficacy, educational level, blue-collar work, and compensation status and moderate evidence for recovery expectations and physical workload as prognostic factors for RTW. Other factors were classified as having limited or inconsistent evidence, and further high-quality studies are needed to understand their impacts. The results from this current update might help in developing effective intervention strategies for RTW and in guiding future research in the field. 


\section{DATA AVAILABILITY STATEMENT}

The original contributions presented in the study are included in the article/supplementary material, further inquiries can be directed to the corresponding author/s.

\section{AUTHOR CONTRIBUTIONS}

HD: involved in conceptualization, data curation, formal analysis, validation, visualization, writing original draft, and writing, reviewing, and editing. AG: prepared conceptualization, data curation, formal analysis, validation, visualization, writing original draft, and writing, reviewing, and editing. RH: contributed in conceptualization, data curation, formal analysis,

\section{REFERENCES}

1. Regel G, Lobenhoffer P, Grotz M, Pape HC, Lehmann U, Tscherne H. Treatment results of patients with multiple trauma: an analysis of 3406 cases treated between 1972 and 1991 at a German Level I Trauma Center. J Trauma. (1995) 38:70-8. doi: 10.1097/00005373-199501000-00020

2. Gomberg BF, Gruen GS, Smith WR, Spott M. Outcomes in acute orthopaedic trauma: a review of 130,506 patients by age. Injury. (1999) 30:431-7. doi: 10.1016/S0020-1383(99)00138-2

3. O'Hara NN, Isaac M, Slobogean GP, Klazinga NS. The socioeconomic impact of orthopaedic trauma: a systematic review and meta-analysis. PLoS One. (2020) 15:e0227907. doi: 10.1371/journal.pone.0227907

4. Statistique des Accidents (2020). Available online at: https://www. unfallstatistik.ch/f/publik/unfstat/pdf/Ts20_f.pdf (assessed 6 April, 2021).

5. Figueredo JM, García-Ael C, Gragnano A, Topa G. Well-Being at work after return to work (RTW): a systematic review. Int J Environ Res Public Health. (2020) 15:7490. doi: 10.3390/ijerph17207490

6. Etuknwa A, Daniels K, Eib C. Sustainable return to work: a systematic review focusing on personal and social factors. J Occup Rehabil. (2019) 29:679-700. doi: 10.1007/s10926-019-09832-7

7. Cancelliere C, Donovan J, Stochkendahl MJ, Biscardi M, Ammendolia C, Myburgh C, et al. Factors affecting return to work after injury or illness: best evidence synthesis of systematic reviews. Chiropr Man Therap. (2016) 24:32. doi: 10.1186/s12998-016-0113-z

8. Schultz IZ, Stowell AW, Feuerstein M, Gatchel RJ. Models of return to work for musculoskeletal disorders. J Occup Rehabil. (2007) 17:327-52. doi: 10.1007/s10926-007-9071-6

9. Clay FJ, Newstead SV, McClure RJ. A systematic review of early prognostic factors for return to work following acute orthopaedic trauma. Injury. (2010) 41:787-803. doi: 10.1016/j.injury.2010.04.005

10. Engel GL. The need for a new medical model: a challenge for biomedicine. Science. (1977) 196:129-36. doi: 10.1126/science.847460

11. Shi Q, Sinden K, MacDermid JC, Walton D, Grewal R. A systematic review of prognostic factors for return to work following work-related traumatic hand injury. J Hand Ther. (2014) 27:55-62; quiz. doi: 10.1016/j.jht.2013.10.001

12. Wade D. Complexity, case-mix and rehabilitation: the importance of a holistic model of illness. Clin Rehabil. (2011) 25:387-95. doi: 10.1177/0269215511400282

13. Fadyl JK, McPherson KM, Schluter PJ, Turner-Stokes L. Factors contributing to work-ability for injured workers: literature review and comparison with available measures. Disabil Rehabil. (2010) 32:1173-83. doi: 10.3109/09638281003653302

14. Steenstra IA, Munhall C, Irvin E, Oranye N, Passmore S, Van Eerd D, et al. Systematic review of prognostic factors for return to work in workers with sub acute and chronic low back pain. J Occup Rehabil. (2017) 27:369-81. doi: 10.1007/s10926-016-9666-x

15. Page MJ, Moher D, Bossuyt PM, Boutron I, Hoffmann TC, Mulrow CD, et al. PRISMA 2020 explanation and elaboration: updated guidance project administration, supervision, validation, visualization, writing original draft, and writing, reviewing, editing. BL: carried out conceptualization, methodology, project administration, supervision, validation, visualization, writing, reviewing, and editing. FL: carried out conceptualization, methodology, data curation, project administration, supervision, validation, visualization, writing original draft, writing, reviewing, and editing. All authors contributed to the article and approved the submitted version.

\section{ACKNOWLEDGMENTS}

We acknowledge P. Vuistiner for his help with statistical analysis. and exemplars for reporting systematic reviews. BMJ. (2021) 372:n160. doi: 10.1136/bmj.n160

16. Moons KG, de Groot JA, Bouwmeester W, Vergouwe Y, Mallett S, Altman DG, et al. Critical appraisal and data extraction for systematic reviews of prediction modelling studies: the CHARMS checklist. PLoS Med. (2014) 11:e1001744. doi: 10.1371/journal.pmed.1001744

17. Hayden JA, van der Windt DA, Cartwright JL, Cote P, Bombardier C. Assessing bias in studies of prognostic factors. Ann Intern Med. (2013) 158:280-6. doi: 10.7326/0003-4819-158-4-201302190-00009

18. Wolff RF, Moons KGM, Riley RD, Whiting PF, Westwood M, Collins GS, et al. PROBAST: a tool to assess the risk of bias and applicability of prediction model studies. Ann Intern Med. (2019) 170:51-8. doi: 10.7326/M18-1376

19. Wells GA, Shea B, O'Connell D, Peterson J, Welch V, Losos M, et al. The Newcastle-Ottawa Scale (NOS) for Assessing the Quality if Nonrandomized Studies in Meta-Analyses (2012). Available online at: http://www.ohri.ca/ programs/clinical_epidemiology/oxford.asp (assessed October 11, 2021).

20. Scholten-Peeters GG, Verhagen AP, Bekkering GE, van der Windt DA, Barnsley L, Oostendorp RA, et al. Prognostic factors of whiplash-associated disorders: a systematic review of prospective cohort studies. Pain. (2003) 104:303-22. doi: 10.1016/S0304-3959(03)00050-2

21. Amick BC III, Lee H, Hogg-Johnson S, Katz JN, Brouwer S, Franche RL, et al. How do organizational policies and practices affect return to work and work role functioning following a musculoskeletal injury? J Occup Rehabil. (2017) 27:393-404. doi: 10.1007/s10926-016-9668-8

22. Ballabeni P, Burrus C, Luthi F, Gobelet C, Deriaz O. The effect of recalled previous work environment on return to work after a rehabilitation program including vocational aspects for trauma patients. J Occup Rehabil. (2011) 21:43-53. doi: 10.1007/s10926-010-9255-3

23. Busse JW, Bhandari M, Guyatt GH, Heels-Ansdell D, Kulkarni AV, Mandel S, et al. Development and validation of an instrument to predict functional recovery in tibial fracture patients: the Somatic Pre-Occupation and Coping (SPOC) questionnaire. J Orthop Trauma. (2012) 26:370-8. doi: 10.1097/BOT.0b013e31822421e2

24. Clay FJ, Newstead SV, D’Elia A, McClure RJ. First return to work following injury: does it reflect a composite or a homogeneous outcome? Occup Environ Med. (2010) 67:730-6. doi: 10.1136/oem.2009.051797

25. Clay FJ, Newstead SV, Watson WL, Ozanne-Smith J, McClure RJ. Biopsychosocial determinants of time lost from work following non life threatening acute orthopaedic trauma. BMC Musculoskelet Disord. (2010) 11:6. doi: 10.1186/1471-2474-11-6

26. Clay FJ, Newstead SV, Watson WL, McClure RJ. Determinants of return to work following non life threatening acute orthopaedic trauma: a prospective cohort study. J Rehabil Med. (2010) 42:162-9. doi: 10.2340/165019 77-0495

27. Clay F, Fitzharris M, Kerr E, McClure R, Watson W. The association of social functioning, social relationships and the receipt of compensation with time to return to work following unintentional injuries to victorian workers. J Occup Rehabil. (2012) 22:363-75. doi: 10.1007/s10926-012-9354-4 
28. Dinh M, Cornwall K, Bein K, Gabbe B, Tomes B, Ivers R. Health status and return to work in trauma patients at 3 and 6 months post-discharge: an Australian major trauma centre study. Europ J Traum Emerg Surg. (2016) 42:483-90. doi: 10.1007/s00068-015-0558-0

29. Eisele A, Dereskewitz C, Kus S, Oberhauser C, Rudolf KD, Coenen $\mathrm{M}$, et al. Factors affecting time off work in patients with traumatic hand injuries-A bio-psycho-social perspective. Injury. (2018) 49:1822-9. doi: 10.1016/j.injury.2018.07.012

30. Ekegren CL, Edwards ER, Oppy A, Liew S, Page R, de Steiger R, et al. Twelvemonth work-related outcomes following hip fracture in patients under 65 years of age. Injury. (2017) 48:701-7. doi: 10.1016/j.injury.2017.01.033

31. Gabbe BJ, Simpson PM, Cameron PA, Ekegren CL, Edwards ER, Page $\mathrm{R}$, et al. Association between perception of fault for the crash and function, return to work and health status 1 year after road traffic injury: a registry-based cohort study. BMJ Open. (2015) 5:e009907. doi: 10.1136/bmjopen-2015-009907

32. Hou WH, Chuang HY, Lee ML. A threshold regression model to predict return to work after traumatic limb injury. Injury. (2016) 47:483-9. doi: 10.1016/j.injury.2015.11.032

33. Hou WH, Sheu CF, Liang HW, Hsieh CL, Lee Y, Chuang HY, et al. Trajectories and predictors of return to work after traumatic limb injury a 2-year follow-up study. Scand J Work Environ Health. (2012) 38:456-66. doi: $10.5271 /$ sjweh.3287

34. Iakova M, Ballabeni P, Erhart P, Seichert N, Luthi F, Deriaz O. Self perceptions as predictors for return to work 2 years after rehabilitation in orthopedic trauma inpatients. J Occup Rehabil. (2012) 22:532-40. doi: $10.1007 /$ s10926-012-9369-x

35. Izadi N, Jamshidi S, Mehrdad R, Nasibi E. Predictors of return to work in patients with occupational hand injury. Hand Surg Rehabil. (2020) 39:218-22. doi: 10.1016/j.hansur.2020.01.009

36. Kendrick D, Vinogradova Y, Coupland C, Christie N, Lyons RA, Towner EL, et al. Getting back to work after injury: the UK Burden of Injury multicentre longitudinal study. BMC Public Health. (2012) 12:584. doi: 10.1186/1471-2458-12-584

37. Kendrick D, Dhiman P, Kellezi B, Coupland C, Whitehead J, Beckett K, et al. Psychological morbidity and return to work after injury: multicentre cohort study. Br J Gen Pract. (2017) 67:e555-64. doi: 10.3399/bjgp17X691673

38. Kimmel LA, Simpson PM, Holland AE, Edwards ER, Cameron PA, de Steiger RS, et al. Discharge destination and patient-reported outcomes after inpatient treatment for isolated lower limb fractures. Med J Aust. (2020) 212:263-70. doi: $10.5694 / \mathrm{mja} 2.50485$

39. Kirkeby L, Frost P, Hansen TB, Svendsen SW. Disability and return to work after MRI on suspicion of scaphoid fracture: influence of MRI pathology and occupational mechanical exposures. PLoS ONE. (2018) 13:e0197978. doi: 10.1371/journal.pone.0197978

40. Kong W, Tang D, Luo X, Yu IT, Liang Y, He Y. Prediction of return to work outcomes under an injured worker case management program. J Occup Rehabil. (2012) 22:230-40. doi: 10.1007/s10926-011-9343-Z

41. Lilley R, Davie G, Ameratunga S, Derrett S. Factors predicting work status 3 months after injury: results from the prospective outcomes of injury study. BMJ Open. (2012) 2:400. doi: 10.1136/bmjopen-2011-000400

42. Luthi F, Deriaz O, Vuistiner P, Burrus C, Hilfiker R. Predicting non return to work after orthopaedic trauma: the Wallis Occupational Rehabilitation RisK (WORRK) model. PLoS ONE. (2014) 9:e94268. doi: 10.1371/journal.pone.0094268

43. Marom BS, Ratzon NZ, Carel RS, Sharabi M. Return-to-work barriers among manual workers after hand injuries: 1-year follow-up cohort study. Arch Phys Med Rehabil. (2019) 100:422-32. doi: 10.1016/j.apmr.2018.07.429

44. Marom BS, Sharabi M, Carel RS, Ratzon NZ. Returning to work after a hand injury: does ethnicity matter? PLoS ONE. (2020) 15:e0229982. doi: 10.1371/journal.pone.0229982

45. Murgatroyd DF, Harris IA, Tran Y, Cameron ID. Predictors of return to work following motor vehicle related orthopaedic trauma. BMC Musculoskeletal Disorders. (2016) 17:171. doi: 10.1186/s12891-016-1019-6

46. Neutel N, Houpt P, Schuurman AH. Prognostic factors for return to work and resumption of other daily activities after traumatic hand injury. J Hand Surg Eur Vol. (2019) 44:203-7. doi: 10.1177/1753193418812645
47. Roesler ML, Glendon AI, O’Callaghan FV. Recovering from traumatic occupational hand injury following surgery: a biopsychosocial perspective. J Occup Rehabil. (2013) 23:536-46. doi: 10.1007/s10926-0139422-4

48. Tay WH, de Steiger R, Richardson M, Gruen R, Balogh ZJ. Health outcomes of delayed union and nonunion of femoral and tibial shaft fractures. Injury. (2014) 45:1653-8. doi: 10.1016/j.injury.2014.06.025

49. Vuistiner P, Luthi F, Erhart P, Scholz SM, Deriaz O. Subjective perceptions as prognostic factors of time to fitness for work during a 4-year period after inpatient rehabilitation for orthopaedic trauma. Swiss Med Wkly. (2015) 145:w14235. doi: 10.4414/smw.2015. 14235

50. Yang Z, Lowe AJ, de la Harpe DE, Richardson MD. Factors that predict poor outcomes in patients with traumatic vertebral body fractures. Injury. (2010) 41:226-30. doi: 10.1016/j.injury.2009. 10.019

51. Diseases GBD, Injuries C. Global burden of 369 diseases and injuries in 204 countries and territories, 1990-2019: a systematic analysis for the Global Burden of Disease Study 2019. Lancet. (2020) 396:1204-22. doi: 10.1016/S0140-6736(20)30925-9

52. Accident at work statistics. Available online at: https://ec.europa.eu/eurostat/ statistics-explained/index.php/Accidents_at_work_statistics\#Accidents_ 2010_to_2018 (assessed April 21, 2021).

53. Franche RL, Cullen K, Clarke J, Irvin E, Sinclair S, Frank J, et al. Workplacebased return-to-work interventions: a systematic review of the quantitative literature. J Occup Rehabil. (2005) 15:607-31. doi: 10.1007/s10926-0058038-8

54. Hlobil H, Staal JB, Spoelstra M, Ariens GA, Smid T, van Mechelen W. Effectiveness of a return-to-work intervention for subacute low-back pain. Scand J Work Environ Health. (2005) 31:249-57. doi: 10.5271/ sjweh. 880

55. Kuijer W, Groothoff JW, Brouwer S, Geertzen JH, Dijkstra PU. Prediction of sickness absence in patients with chronic low back pain: a systematic review. J Occup Rehabil. (2006) 16:439-67. doi: 10.1007/s10926-0069021-8

56. Huijs JJ, Koppes LL, Taris TW, Blonk RW. Differences in predictors of return to work among long-term sick-listed employees with different self-reported reasons for sick leave. J Occup Rehabil. (2012) 22:301-11. doi: 10.1007/s10926-011-9351-z

57. Cochrane Methods Prognosis Group Methodological Tools. Available online at: http://methods.cochrane.org/prognosis/tools (assessed April 21, 2021).

58. Boyle E, Cassidy JD, Cote P. Determining the reliability and convergent validity of a return-to-work status questionnaire. Work. (2019) 63:69-80. doi: 10.3233/WOR-192909

59. Steenstra IA, Lee H, de Vroome EM, Busse JW, Hogg-Johnson SJ. Comparing current definitions of return to work: a measurement approach. J Occup Rehabil. (2012) 22:394-400. doi: 10.1007/s10926-0119349-6

Conflict of Interest: The authors declare that the research was conducted in the absence of any commercial or financial relationships that could be construed as a potential conflict of interest.

Publisher's Note: All claims expressed in this article are solely those of the authors and do not necessarily represent those of their affiliated organizations, or those of the publisher, the editors and the reviewers. Any product that may be evaluated in this article, or claim that may be made by its manufacturer, is not guaranteed or endorsed by the publisher.

Copyright (c) 2022 Duong, Garcia, Hilfiker, Léger and Luthi. This is an open-access article distributed under the terms of the Creative Commons Attribution License (CC $B Y)$. The use, distribution or reproduction in other forums is permitted, provided the original author(s) and the copyright owner(s) are credited and that the original publication in this journal is cited, in accordance with accepted academic practice. No use, distribution or reproduction is permitted which does not comply with these terms. 